\title{
Acropolis of the Middle-West: Decay, Renewal, and Boosterism in Cleveland's University Circle
}

J. Mark Souther

Cleveland State University, m.souther@csuohio.edu

Follow this and additional works at: https://engagedscholarship.csuohio.edu/clhist_facpub

Part of the American Studies Commons, and the United States History Commons

How does access to this work benefit you? Let us know!

Publisher's Statement

@ 2011 Sage Publications.

\section{Original Citation}

Souther, J. M. (2011). Acropolis of the middle-west: Decay, renewal, and boosterism in Cleveland's University Circle. Journal of Planning History, 10(1), 30-58.

Repository Citation

Souther, J. Mark, "Acropolis of the Middle-West: Decay, Renewal, and Boosterism in Cleveland's University Circle" (2011). History Faculty Publications. 24.

https://engagedscholarship.csuohio.edu/clhist_facpub/24

This Article is brought to you for free and open access by the History Department at EngagedScholarship@CSU. It has been accepted for inclusion in History Faculty Publications by an authorized administrator of EngagedScholarship@CSU. For more information, please contact library.es@csuohio.edu. 


\title{
Acropolis of the Middle-West: Decay, Renewal, and Boosterism in Cleveland's University Circle
}

\author{
J. Mark Souther
}

\begin{abstract}
In the mid-twentieth century, Cleveland, Ohio's University Circle exemplified an emerging trend in which urban universities and other private institutions engaged in urban renewal. Situating the story of University Circle within the context of contemporary concerns about urban decay, deindustrialization, and suburbanization, the author argues that University Circle institutions were not simply trying to facilitate their own expansion. Rather, they were equally determined to create a setting appropriate to their regional, national, and even international reputations, as well as to advance the idea that an educational, medical, and cultural district could help reposition and rebrand a sagging industrial city. To do so, institutional leaders sought to make University Circle a bulwark against urban problems, which endeared them to suburbanites while constraining their relations with surrounding urban neighborhoods.
\end{abstract}

\section{Keywords}

Cleveland, urban renewal, universities, ed-med districts, boosterism, African Americans, University Circle, riots

In 1970, referring to Cleveland, Ohio's University Circle, a 488-acre educational, medical, and cultural hub four miles east of downtown, a planning consultant's report noted:

The University Circle community finds itself at a crossroads. It has a 3/4 billion dollar investment in a physical plant which constitutes a veritable Acropolis of the Middle West. The facilities of its $33 \mathrm{mem}$ ber institutions are admirably suited to serve the needs of a broad community, encompassing scholars, artists, scientists, and students from all over the country and, indeed, the world. Yet, its ability to fulfill its function is gravely impaired by the gradual social and physical disintegration of the larger community of which it is a physical part its surrounding neighborhoods and the City of Cleveland as a whole. ${ }^{1}$

Reflecting after the failure of an urban renewal project that had promised a decade earlier to rehabilitate the city's east side, the report suggested both the dream and the dilemma that planners faced 
as they sought to make University Circle a vehicle for reversing the onset of urban decline in what was to become one of the most deindustrialized American cities. ${ }^{2}$ Indeed, Cleveland's emergence as a city with two hubs - the business-, government-, and retail-oriented downtown, and the culture-, education-, and health care-oriented University Circle - coincides with the beginning of the transformation of the Great Lakes region into the Rust Belt.

Although the topic of urban renewal is well researched, historians have usually focused on downtown renewal or housing. ${ }^{3}$ Educational, medical, and cultural districts, which have grown into major economic engines in recent decades, are largely absent in the historiography. ${ }^{4}$ The University Circle venture, which marshaled not only universities but also museums, hospitals, religious congregations, and other institutions in the campaign for renewal, typifies this understudied phenomenon and resembles similar districts elsewhere-New York's Morningside Heights, Chicago's Hyde Park, and Philadelphia's University City among them. While renewal projects nationally proceeded from mostly local efforts by private interests in the late 1940s and early 1950s to mostly federally supported efforts in the late 1950s and 1960s, University Circle undertook a major renewal program that anticipated federal funding yet ultimately relied on private initiative in the 1960s. Renewal projects nationally also trended toward downtown plans by the late 1950s, but Cleveland visionaries also worked to bolster their city's separate cultural center as the hub of a new economy, an icon of a new urban image, and a bulwark against decay. ${ }^{5}$

This essay traces how University Circle in the 1950s and 1960s reflected a coordinated private effort to undertake and narrate to the public a major renewal plan; counter charges that the district was attempting to insulate itself from the surrounding city while catering to suburbanites; and reverse public perceptions of the area as dangerous, particularly against the backdrop of two major race riots. Although Circle leaders ultimately failed to garner sufficient federal funding to remake their surroundings, their actions offer a window into both the power and the constraints of major urban institutions. Moreover, while historians have pointed to the power and limits of racial liberalism in the postwar urban North, this essay probes a little-examined aspect of northern civic leaders' larger campaigns to mitigate decline by examining the extent to which large institutions' leaders were cognizant of and responsive to the roots of the urban decay that they feared might engulf them. ${ }^{6}$

\section{University Circle in Historical Perspective: From Borderland to Institutional “Acropolis"}

In order to understand how University Circle assumed such a critical role in the drama of bolstering postwar Cleveland, it is essential to examine the district's development prior to the 1940s. A distinct cultural center emerged in the early 1880s when Western Reserve University (WRU) and the Case School of Applied Science (which consolidated as Case Western Reserve University in 1967) opened on Euclid Avenue. The presence of two colleges and a nearby streetcar turnaround suggested the name University Circle, but the area was perhaps equally known as Wade Park, the name given to both a park and a residential allotment on land owned by Western Union Telegraph founder and Case cofounder Jeptha Homer Wade. As industrialists built mansions in the Wade Park allotment, it began to transform from what historian John Stilgoe would call a "borderland," a sylvan landscape of country estates, into an eastern anchor of the famed Millionaires' Row on Euclid Avenue ${ }^{7}$ (Figure 1). After 1900, more institutions, including an art museum, art school, music conservatory, and hospitals, joined WRU and Case. The mid-1920s saw the first move to adopt a master plan for the district after civic leaders commissioned the Olmsted Brothers-designed Fine Arts Garden around Wade Park Lagoon, but the Great Depression intervened and precluded its implementation. ${ }^{8}$ 


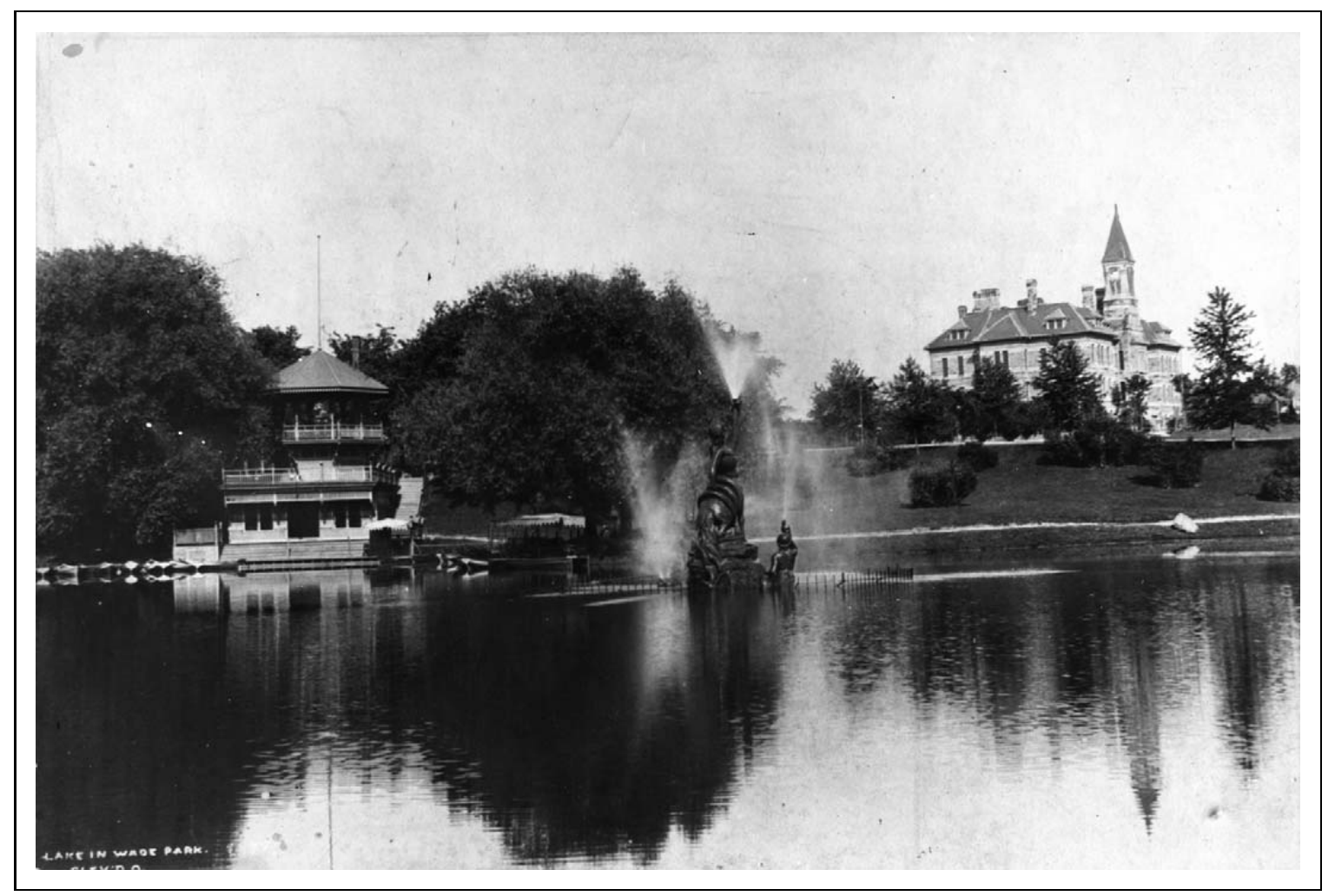

Figure I. Wade Park Lagoon and Adelbert College, the men's college of Western Reserve University, ca. 1900. Around the turn of the twentieth century, University Circle was a "borderland" just beginning to feel the eastward residential expansion of Cleveland's elite. Source: Cleveland Press Collection, Cleveland State University.

Following the Depression and World War II, Cleveland experienced a brief but impressive boom, its population swelling from 878,336 in 1940 to 914,808 in 1950. Mirroring a national trend, Clevelanders interpreted the buzz of activity as evidence that prompt, effective planning was critical to ensure orderly growth. They could hardly have guessed that the boom would be short-lived in the Great Lakes region and, indeed, offset by suburbanization and deindustrialization. University Circle, like Cleveland, was bursting at the seams in the late 1940s and 1950s. It became increasingly crowded with new buildings and many more cars as doctors, nurses, patients, professors, students, and arts patrons chose suburban homes on the "Heights" to the east. Its universities also paralleled a national trend of soaring enrollments in the great democratization of higher education, necessitating their own building booms. Case Institute of Technology, headed since its 1947 name change by Dr. T. Keith Glennan, a leading figure in the national scientific community (including as chairman of the U.S. Atomic Energy Commission, 1950-1952, and National Aeronautics and Space Administration [NASA] Administrator, 19581961), mirrored the Cold War-era investment of federal funding that tied large American universities to the military-industrial complex. ${ }^{9}$

Despite the exhilaration Circle leaders felt when viewing the growth of their institutions, they cast a wary eye westward to the deteriorating conditions in Hough, a two square mile neighborhood extending from East 55th to East 105th streets between Euclid and Superior avenues (Figures 2 and 3). Hough was rapidly filling with African Americans displaced by urban renewal projects in the Cedar-Central neighborhood to the south, Cleveland's counterpart to New York's Harlem, Chicago's South Side, and Detroit's Paradise Valley. Circle leaders also grew concerned about the Euclid-East 105th area, sandwiched between Hough and University Circle. Known as Cleveland's "second downtown," it had several blocks of hotels, theaters, restaurants, bowling 


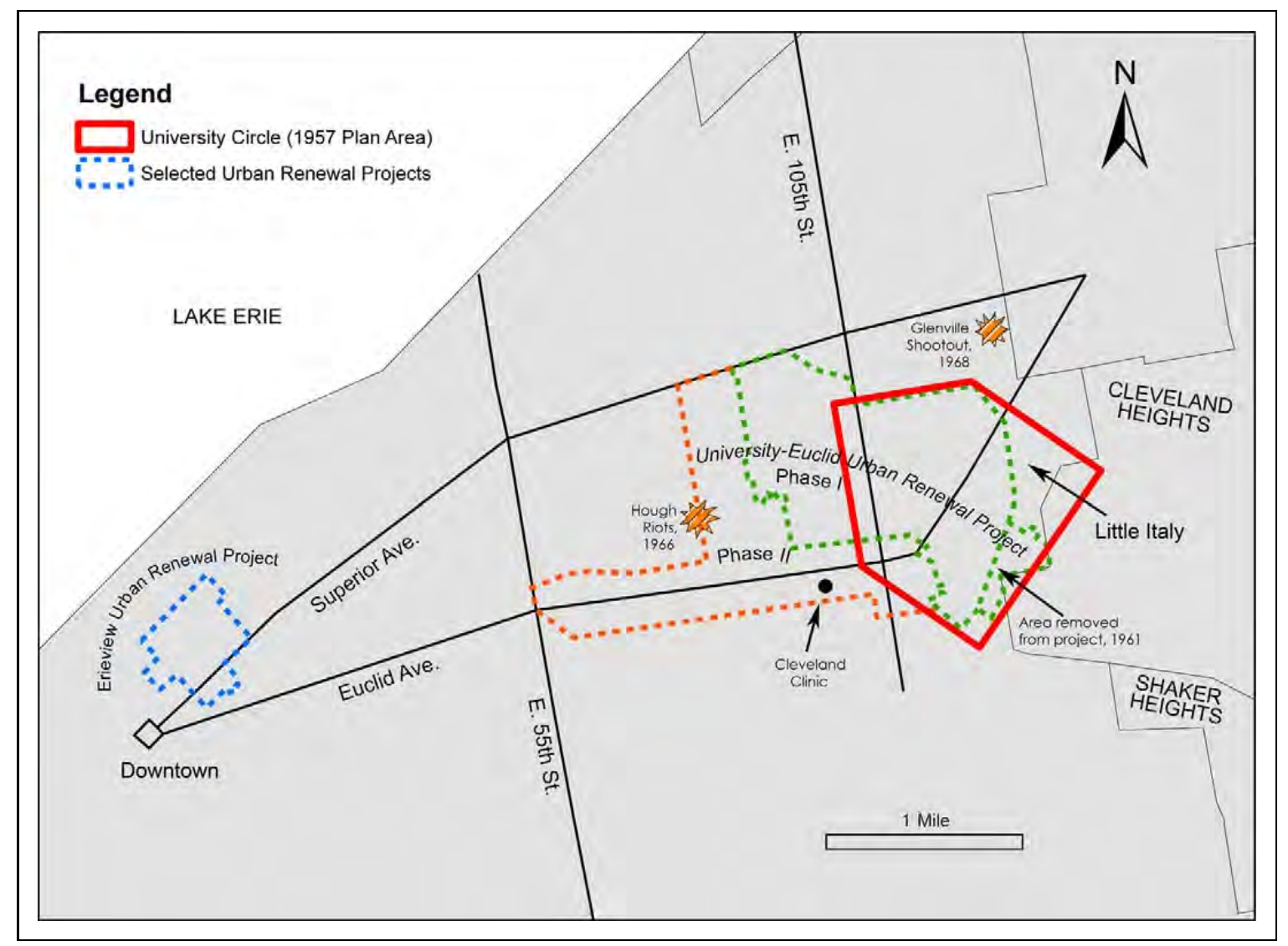

Figure 2. Map of Cleveland's East Side, showing University Circle. By Todd M. Michney. Note: The indicated locations of the city's two major race riots correspond to the sites where each began. Both riots spread over multi block areas and spurred additional isolated incidents in other parts of the city.

alleys, and stores and, until the area's first enclosed regional mall opened in Cleveland Heights in 1963, served as the primary shopping center on the city's east side. By the late 1950s, however, the sagging Euclid-East 105th area was beginning to be conflated with Hough in the local imagination. It was also disturbingly close to the cultural district that suburban Cleveland's elite was cultivating.

Although they now usually listed Cleveland Heights or Shaker Heights rather than Cleveland as their residence, University Circle leaders remained psychologically invested in the Circle. ${ }^{10}$ Institutional leaders, as one report recalled, "had done considerable soul searching. They asked themselves - Do we escape from the obsolescence and decay which we see crowding in around us and move to another location or do we reinforce our commitment to the city?" Two in particular, Temple Tifereth Israel, a nationally prominent Jewish synagogue, and Mt. Sinai Hospital, lay on the border between Hough and University Circle and faced considerable internal pressure in the 1950s to move to the suburbs. ${ }^{11}$ Among their concerns were the need to find space for physical expansion (including accommodating growing numbers of suburban motorists), the physical decay they saw in surrounding areas, and rapid racial change. Although University Circle stood apart from Morningside Heights and Hyde Park in that most of its academic, medical, and museum professionals had already made the jump to the suburbs, its institutions became similarly infused with a fortress mentality that went along with its emerging "acropolis" image. This mentality surfaces in repeated institutional references to University Circle as an acropolis as well as to its leaders' sense of it as an embattled stronghold ringed by decay. 


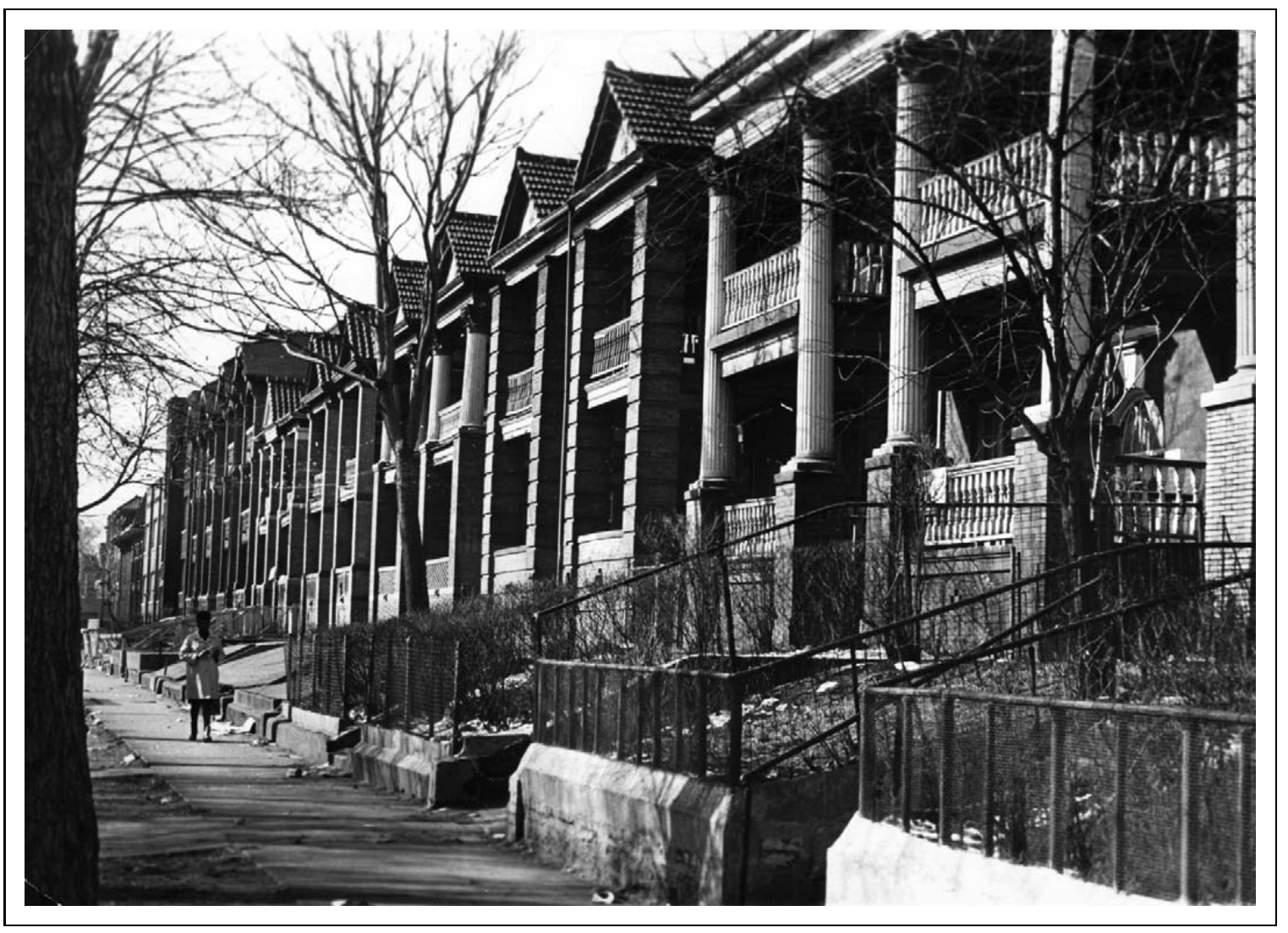

Figure 3. Tenements on East 75th Street in the Hough neighborhood, 1966. Source: Cleveland Press Collec tion, Cleveland State University.

\section{Planning “A Brainworkers' City Within a City:” The Adams, Howard \& Greeley Plan of 1957}

In the early 1950s, Circle leaders seized the initiative, not only seeking greater cooperation among the institutions as they contemplated expansions in a constrained area but also hoping University Circle might be a citadel from which they could defend their museums, their colleges, and even their homes from the threat of urban decay. In December 1951, four years after Columbia University in New York founded Morningside Heights Inc., representatives of nine University Circle institutions, led by Western Reserve University, moved toward forming a similar entity to discuss "matters of mutual interest and concern." Among the concerns of the University Circle Conference Committee (UCCC) was battling the conversion of Wade Park mansions into multifamily apartments and rooming houses, which officials worried might diminish the neighborhood's character, making future institutional use untenable. Lacking sufficient funds to launch a major program to coordinate development in the Circle, in 1955 the UCCC sprang into action when Elizabeth Ring Mather walked into Keith Glennan's office and handed him a check to commission a planning firm to draw up a proposal for guiding the Circle. ${ }^{12}$

Mather was the widow of Cleveland-Cliffs Iron Company magnate William G. Mather, who had led the effort to realize a Daniel Burnham-designed City Beautiful project known as the Group Plan in downtown Cleveland in the early 1900s. A half-century later, concerned that worsening urban decay on the city's east side threatened University Circle's stability, Elizabeth Mather emerged as a steward for a revival of the 1920s notion of a cultural "group plan." Understanding that the 
scope of the undertaking, encompassing several large, often competing institutions, required careful planning, she had consulted New York planner Robert Moses before deciding to help fund a twentyyear master plan. ${ }^{13}$ Her gift spurred the Leonard C. Hanna Jr. Fund, named for a mining baron and philanthropist and administered principally by attorney and longtime Circle institutional backer Harold T. Clark, to commit \$2 million, to which Republic Steel, Standard Oil Company of Ohio (Sohio), other industries, and old-line Clevelanders added another $\$ 1$ million. ${ }^{14}$

Glennan and his associates selected the Cambridge, Massachusetts, planning firm of Adams, Howard \& Greeley in large part because one of its principals, John T. Howard, was a former Cleveland City Planning Commission director before he left to teach at MIT and thus possessed an intimate knowledge of the city. Another key factor in the decision was that the firm's appointed project director, renowned city planner Kevin Lynch, was the only one who pointed to the need to pair institutional expansion with redevelopment beyond the Circle. ${ }^{15}$ The resulting plan, possibly influenced by Lynch's travels in Europe and completed in 1957, created a $\$ 175$ million blueprint for orderly institutional growth, and emphasized the same bricks-and-mortar approach that characterized most mid-century renewal efforts. Lynch concentrated on consolidating land uses into two adjacent nodes, one "academic-medical" and the other a "public-oriented leisure-time area." He recommended lowering Euclid Avenue beneath a new plaza housing a university center to "bring together the great variety of professionals;" closing several streets and creating a four-lane loop road around the academic-medical node with parking garages along its arc; adding new housing for students and institutional staff; and demolishing dozens of houses to create a "Greenway" for the WRU campus $^{16}$ (Figures 4 and 5).

The planners were careful to integrate institutional needs with recommendations for attentiveness to nearby areas, cautioning that University Circle "is not an entity in itself, but is part and parcel of its surroundings." They concluded that of the four surrounding areas, only the "extremely stable" Cleveland Heights provided a suitable "anchor" for the district. Glenville, located to the north of the Circle, was "one of the best residential areas for Cleveland's Negro community" and merited conservation, as did Little Italy to the east. Hough, on the other hand, needed major remedial action. Implicitly underscoring the need to be concerned about the conditions beyond the Circle, the plan also acknowledged that the dearth of available land in the plan area would necessitate finding sites for institutional staff housing, and it recommended eastern Hough and, significantly, Little Italy as two suitable spots for such development. ${ }^{17}$

The 1957 plan also organized the University Circle Development Foundation (UCDF), an umbrella agency representing Circle institutions. From its inception, and despite its growing number of member institutions, the foundation was, at its heart, a creature of the Circle's three largest institutions-WRU, Case, and University Hospitals. As a result of their size and ambitions, these three institutions especially needed to coordinate their planning. ${ }^{18}$ Its first president, Neil J. Carothers, was an Alabama native who, after serving with Glennan on the Atomic Energy Commission in the early 1950s, moved to Shaker Heights in 1954 and became an officer of a major Cleveland construction firm. UCDF's main functions included purchasing property to hold in trust for future institutional expansion, as well as coordinating planning, parking, landscaping, and eventually policing in the Circle. ${ }^{19}$ While UCDF focused most of its resources on these responsibilities, it also served as a mouthpiece for the combination of boosterism and fear of urban decay that marked many mid-century American cities. From the start, UCDF went beyond merely coordinating the Circle's development, promising to remake the anticipated dynamo of the Cleveland economy. University Circle's role was to stave off deindustrialization, rebrand Cleveland, and reverse or at least arrest the spread of urban decay on the city's east side, not to restore lost urban greatness.

Referencing a popular marketing slogan launched by the Cleveland Electric Illuminating Company in 1944 to get a jump on the expected postwar resumption of urban rivalries, an article in the Case Alumnus asserted hopefully that the master plan would "help make Cleveland, more than ever 


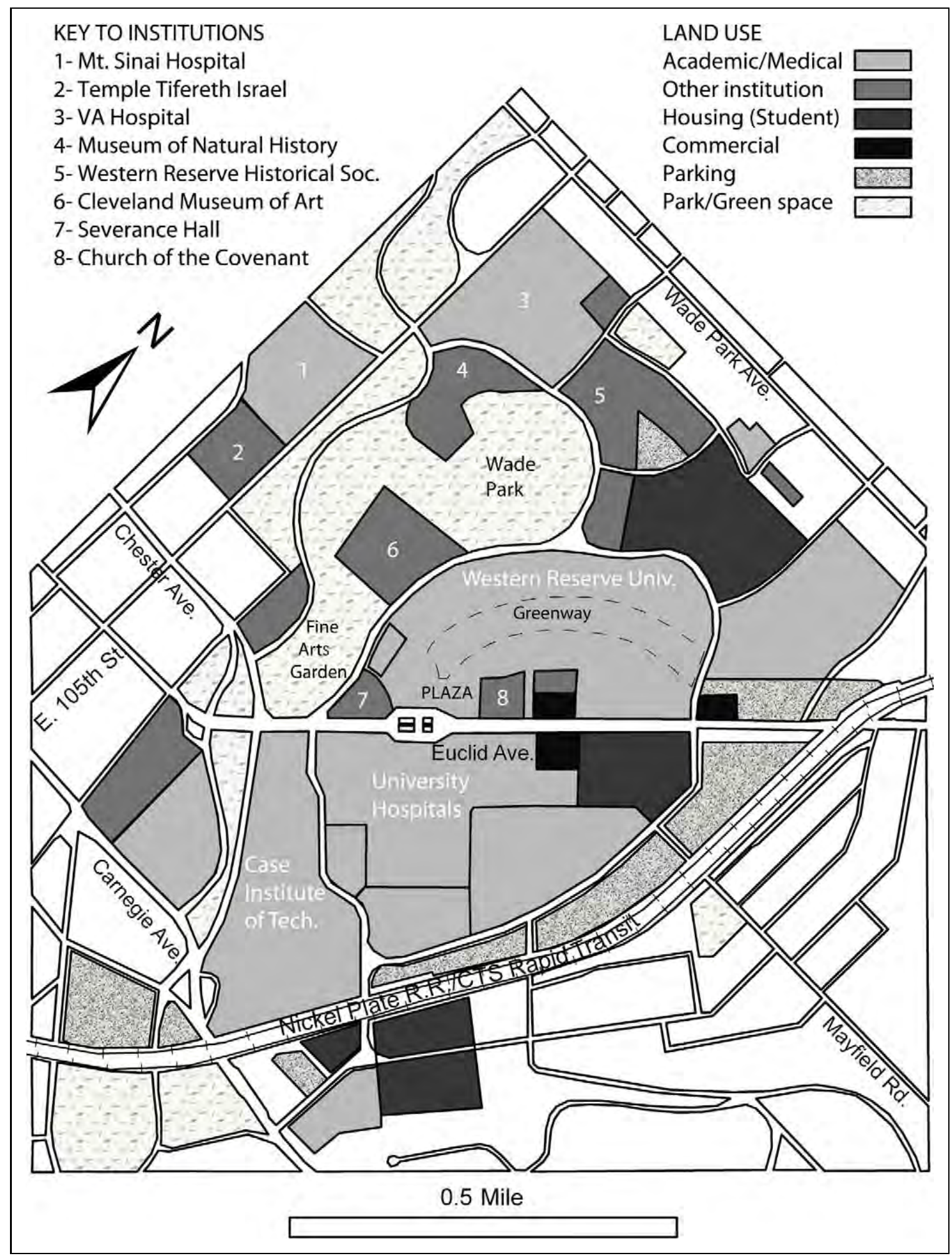

Figure 4. 1957 University Circle Plan. Adapted from maps in the University Circle General Plan by Adams, Howard \& Greeley. By Todd M. Michney. 


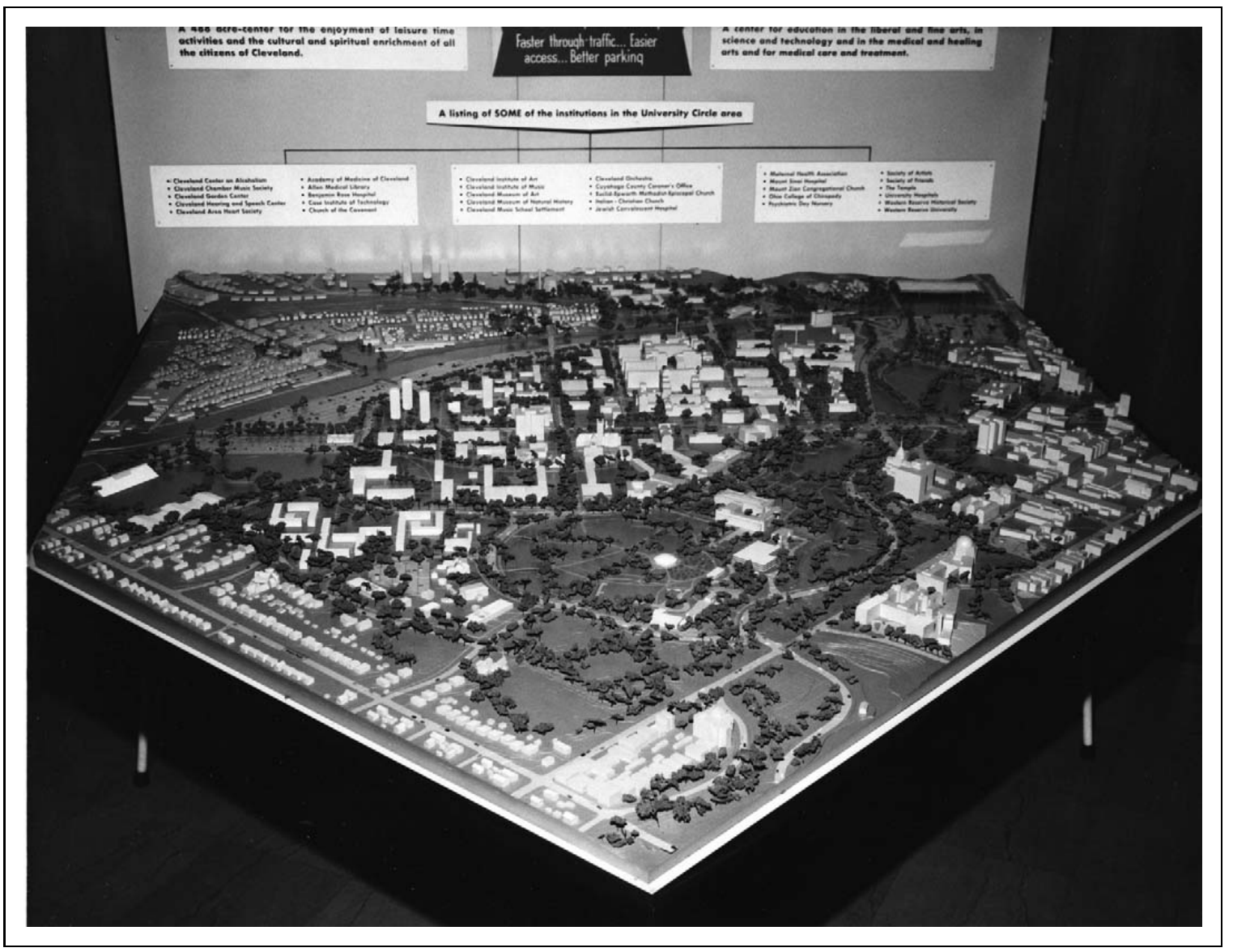

Figure 5. Scale model of the University Circle Plan, with the northwest corner in foreground. The plan pre scribed a collection of Modernist buildings arrayed around green spaces. Source: Cleveland Press Collection, Cleveland State University.

before, 'the best location in the nation.",20 Indeed, with its 6,412 full-time and 2,276 part-time workers, University Circle's $\$ 36$ million payroll placed it on par with the area's sixth largest private corporate employer, and its net assets rivaled those of Sohio, the city's fourth largest corporation. Yet in 1963, the Plain Dealer reported that few Clevelanders gave much attention to University Circle's growing role in the city's economy. ${ }^{21}$ To acquaint Clevelanders with University Circle, UCDF began beefing up its public relations efforts, portraying the Circle as an emblem of a city on the move. Beginning in 1962, the foundation staged annual open houses to encourage locals to tour the district. A "steady stream of families dressed in their Sunday best" turned out to tour the museums, attend concerts, and even square off in games with a UNIVAC computer at Case. UCDF also worked to add new signage, outdoor lighting, and street furniture to brand the Circle in the public's mind. ${ }^{22}$ Its institutions surely viewed such efforts as outward signs of connection to the broader city at a time when they were spending considerable time and money setting the Circle apart from an increasingly troubled Cleveland.

UCDF emphasized that University Circle was a distinct asset in coping with national economic changes. The foundation urged local chamber of commerce leaders as well as railroad companies to trumpet University Circle in their industrial recruiting efforts. ${ }^{23}$ Its leaders found reassurance in Mayor Anthony J. Celebrezze's remarks at a 1961 business luncheon that University Circle was "our educational and cultural 'treasure chest." Although southern California and Massachusetts were blazing ahead in attracting "new technology" enterprises, he observed, "Cleveland has the 
brain power and through University Circle and other development will attract more along with the new business which uses it." 24

University Circle planners also pointed to the need for a place that softened the hard edges of a gritty industrial city. The tone for this discourse emerged in the master plan itself, which had asserted that University Circle could "become a powerful symbol for urban America of the future .... It can fulfill a function similar to the cathedral square of medieval times or the villages of eighteenth-century New England." Echoing the humanistic tone of the planners, a 1959 feature in the Plain Dealer Pictorial Magazine dubbed University Circle "a brain workers' city within a city." Subsequent UCDF publications also called attention to the softer side of an enterprise known chiefly for bricks and mortar, pointing for instance to the annual planting of thirty thousand geraniums. ${ }^{25}$

Yet, UCDF's most overlooked role during the late 1950s and 1960s was advancing the view that University Circle was a critical "symbol of stability and quality in an area of the city marked by blight and decay." 26 Circle leaders were interested in the state of surrounding areas, notably Hough, Euclid-East 105th, and Little Italy, which they believed did not provide a setting consonant with their national and international ambitions. Heeding recommendations in the master plan, UCDF and its member institutions sought ways to transform the neighborhoods ringing the district. UCDF was, however, careful to note that it would limit outreach "to cases where our assistance was actually solicited," suggesting something short of cementing close ties with its neighbors. ${ }^{27}$ Instead, the foundation tried to transform its periphery by working with member institutions to promote the housing of students, professionals, and workers affiliated with those institutions, even as it bought hundreds of dwellings, razed them, and held the land in trust for future institutional expansion.

Lacking a mandate to acquire properties outside the Circle, UCDF supported efforts to "seed" housing on its fringes that it feared might slip into decay. To this end, it persuaded the Cuyahoga Metropolitan Housing Authority to reserve up to fifty apartments for Mt. Sinai and University Hospitals' interns and residents in a new housing project planned for Ansel Road in eastern Hough, arguing it would promote racial balance in the development and also "go a long way towards assuring its stability." On the southwestern fringe of the Circle, the foundation purchased the twelvestory, 1920s-era Tudor Arms Hotel, which had turned into what UCDF Vice President Oliver Brooks called a "fast and loose" hotel, to convert into graduate student dormitories. ${ }^{28}$

Sometimes its actions spurred opposition. On University Circle's eastern edge, in Little Italy, UCDF attempted to acquire property for Case's expansion. Located across the Nickel Plate Railroad tracks from Case and University Hospitals and hemmed in to the east by a steep bluff leading up to Cleveland Heights, Little Italy had emerged in the 1880s as one of a few Italian immigrant enclaves in Cleveland. By the mid-twentieth century, it had solidified its reputation as a protected neighborhood that was wary of encroaching development and racial integration as many of its ethnic residents were streaming toward the suburbs. As historian Todd M. Michney demonstrates, however, Little Italy's biggest threat lay not in "racial residential transition" but rather in suburban flight and the encroachment of Circle institutions. ${ }^{29}$ In 1959, when UCDF pushed for a new state law to enable it to exercise eminent domain over holdout property owners, wary residents mobilized to fight what they feared would spell the end of Little Italy. Councilman Paul J. DeGrandis Jr. complained that "when the people in my ward received their first letter from the foundation about its program they looked around the back of the mailman to see if a bulldozer was coming up the street to put them out of their homes .... We are not opposed to the development, but we do not care to be listed on a chart as just another set of pins." 30

Determined to stop the institutional juggernaut, some fifty Little Italy residents organized as the Alta Early Settlers Association and caravanned to Columbus to protest. Several blocks away, a number of prominent African Americans who lived in Wade Park feared Western Reserve's expansion 
into the area between East 115th and East 118th streets to the north of Euclid Avenue. As affluent Clevelanders left for the Heights, Wade Park had become a favored address for upwardly mobile blacks. It was arguably the choicest neighborhood accessible to African Americans in 1959, for only a small handful of blacks had been able to obtain homes on the western fringe of the status suburb of Shaker Heights. Although the Wade Park residents were organized through a neighborhood association and may have had more to lose than the Italian Americans who could move more freely to most suburban communities, they opted to have DeGrandis represent their interests in Columbus rather than join the Little Italy group. The Ohio Senate frowned on the bill, leading UCDF to scuttle the plan out of concern for the Circle's image. ${ }^{31}$ Although the Circle made only limited inroads into Little Italy, it acquired and demolished most of the black residences in Wade Park. Yet the institutions showed perhaps greater concern not for the land needed for actual expansion (a task for which they were equipped) but rather the character of the area to their immediate west. $^{32}$

\section{Section 1 I 2 and the Search for Urban Renewal: The University-Euclid Plan}

Federal urban renewal became the linchpin in plans to remake both the Circle and the neighborhoods beyond its borders. In 1958, Neil Carothers joined Julian H. Levi, head of the University of Chicago's South East Chicago Commission, and leaders from several other prominent universities in lobbying Congress to amend the Housing Act of 1949 to give universities a role in leveraging federal urban renewal funds. Upon passage of the Housing Act of 1959, Carothers led the way in getting Cleveland officials to enlarge the scope of their project, creating the University-Euclid Urban Renewal Project, which encompassed University Circle. Under Section 112 of the Housing Act, the City of Cleveland could claim the money spent by the universities for their own expansion as part of its contribution to urban renewal. Thus, University Circle joined the ranks of a select few universities-notably Chicago, Columbia, and Pennsylvania-in working with municipal governments to redevelop surrounding areas. What made University Circle unique was that, unlike many university-led urban renewal projects, its plan represented a panoply of institutions clustered in a compact area. ${ }^{33}$

Failure to obtain expected levels of foundation funding two years into the University Circle redevelopment enterprise - a casualty of competition for finite resources between the budding University Circle and the struggling downtown district - coupled with the defeat of eminent domain, produced a new sense of urgency. Less volcanic than UCDF's eminent domain bid, Section 112 appeared the best hope of leveraging the funding necessary for institutional growth while also helping rehabilitate surrounding neighborhoods. ${ }^{34}$ Mayor Celebrezze and his urban renewal chief James Lister proposed an antidote to an emerging problem for Cleveland - an educational, medical, and cultural district divided from downtown by four miles of neighborhoods in various stages of decay. In part they took their cue from recommendations for revitalizing downtown found in a 1959 Cleveland City Planning Commission plan underwritten by four local foundations, including the Cleveland Development Foundation, a five-year-old urban renewal action group financed by the city's industrial brass. On the heels of the plan, the city hired the famed architect I. M. Pei to design the 125-acre Erieview, the largest, most ambitious downtown renewal plan in the United States. City leaders hoped to entice major corporate offices to fill new downtown skyscrapers and convince thousands of Clevelanders to try downtown living. Cleveland's planners would also attempt to use Erieview and University Circle as anchors for a revitalized corridor to either side of Euclid Avenue. ${ }^{35}$

University-Euclid, which was to combine clearance and rehabilitation, included plans for closing several through streets; building three major shopping centers, high-rise apartments in the EuclidEast 105th area and at Euclid Avenue and Mayfield Road; and opening up new land for industrial expansion to either side of Euclid Avenue west of East 79th Street and for a research park along the 


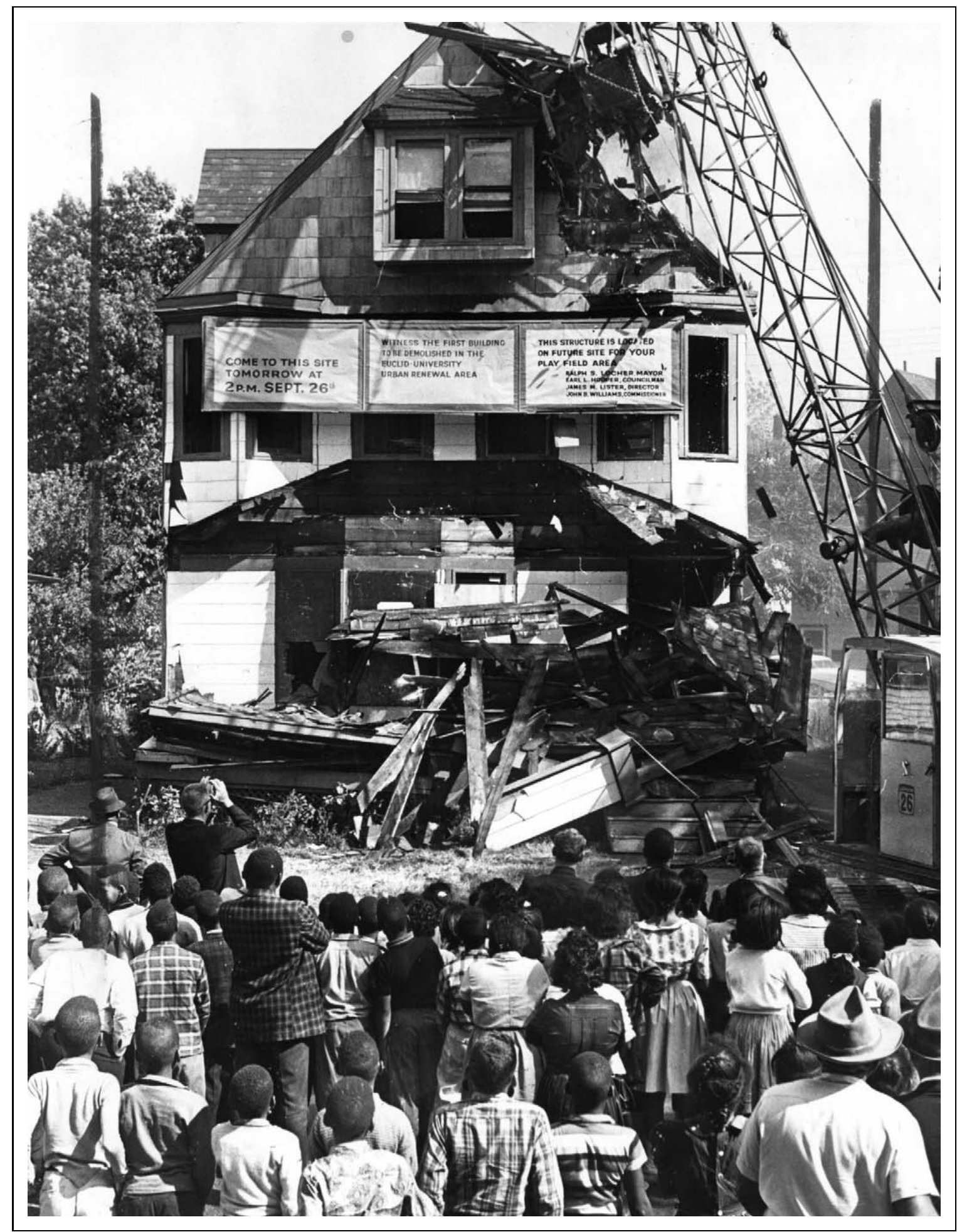

Figure 6. The first house (on East 86th Street) demolished under the University Euclid urban renewal project, 1963. Suffering insurmountable challenges, the urban renewal project failed to produce the results that Circle institutions had anticipated following the passage of the Housing Act of 1959. Source: Cleveland Press Collec tion, Cleveland State University. 
Nickel Plate Railroad. Although UCDF maintained an active interest in it, University-Euclid was essentially the responsibility of the city's urban renewal department ${ }^{36}$ (Figure 6).

As Circle leaders worked to promote University-Euclid, they understood the potential for public outcry. This realization prompted a flurry of image maintenance, with UCDF painting its urban renewal involvement in the rosiest of hues. In keeping with its emphasis on the Circle as a humanizing force in the city, the foundation dubbed University-Euclid "A Project for Mankind." 37 In 1962, with memories of the Little Italy eminent domain fight still fresh in Circle officials' minds, a UCDF report urged that the first land condemnations be made outside the Circle to avoid any charges that the foundation had received the power of eminent domain. ${ }^{38}$ The report also reflected UCDF's understanding that its wholesale takeover of properties in the East 115th to 118th Street area, which "leaves many good Negro families with no clear place to move," placed its institutions on the defensive in explaining their actions to African Americans. ${ }^{39}$

Apart from projects contingent upon urban renewal funds, the Circle's execution of some of the central aspects of its twenty-year plan, including a loop road, drew the ire of some in the community. The Friends of the Circle, an organization formed by faculty, students, and staff of Circle institutions in the early 1960s, combated what its members saw as relentless, self-aggrandizing institutional redevelopment, arguing that the road was not only a threat to the leafy verdure of the Circle but also a symbol of UCDF's attitude toward its neighbors. The road would, wrote the Friends' Circle Review editor and WRU English professor Helen Weinberg, create "the University's Maginot Line." It was, she noted, one thing for UCDF to fight against crime and disease, but this stance begged the question of "what the Foundation is for." 40 One economics professor thought he knew the answer to that question, arguing that UCDF wanted to make the Circle "an isolated island, free of grocery stores, taverns and shops" ${ }^{41}$ (Figure 7).

If the leading Circle institutions' leaders hoped to rid Euclid Avenue and side streets of tightly packed storefronts and rooming houses, they also envisioned building a \$100 million urban research park on sixty-five acres bounded by East 100th Street, Carnegie Avenue, and the Nickel Plate Railroad that might be Cleveland's answer to Boston's Route 128, Stanford Research Park in Silicon Valley, and Philadelphia's new University City Science Center. ${ }^{42}$ Spearheaded by Keith Glennan shortly after the creation of the University-Euclid project and advanced by a newly formed corporation comprised of Case, WRU, and UCDF, the University Circle Research Center (UCRC) promised to position Cleveland as a major research and development center for existing and prospective industries. Its president, Willard W. Brown, a former division president of the Clevite Corporation, a bearings manufacturer and major defense contractor, surely understood the difficulty of his task. The mid-1960s seemed a pivotal moment for metropolitan regions like Northeast Ohio vying for lucrative federal science and technology grants. Since the Korean War, the Great Lakes region's share of military contracts had contracted sharply, and nearly all newly minted PhDs seeking industrial positions were leaving the region. As in other Great Lakes cities, Cleveland's older heavy industries were not positioned to drive economic expansion to match that of the Sunbelt or East and West Coasts. Nor was it given that industrial research divisions would choose an urban park, even with its suburban appearance, over their own site on cheap land near newer suburbs ${ }^{43}$ (Figure 8).

In 1964, after purchasing nine acres from the city, the University Circle Research Center Corporation signed Erieview developer James W. Galbreath to construct at least three multistory buildings in a campus-like setting akin to similar projects in suburban areas, yet it took two additional years to attract enough committed firms to break ground. In 1968, the first building opened, housing the research divisions of Harris-Intertype Corporation (electronics) and Chase Brass \& Copper Company, corporate headquarters for the Warner \& Swasey Company (machine tools and military instruments), and several smaller tenants. Circle leaders seemed to have reason to celebrate as the 


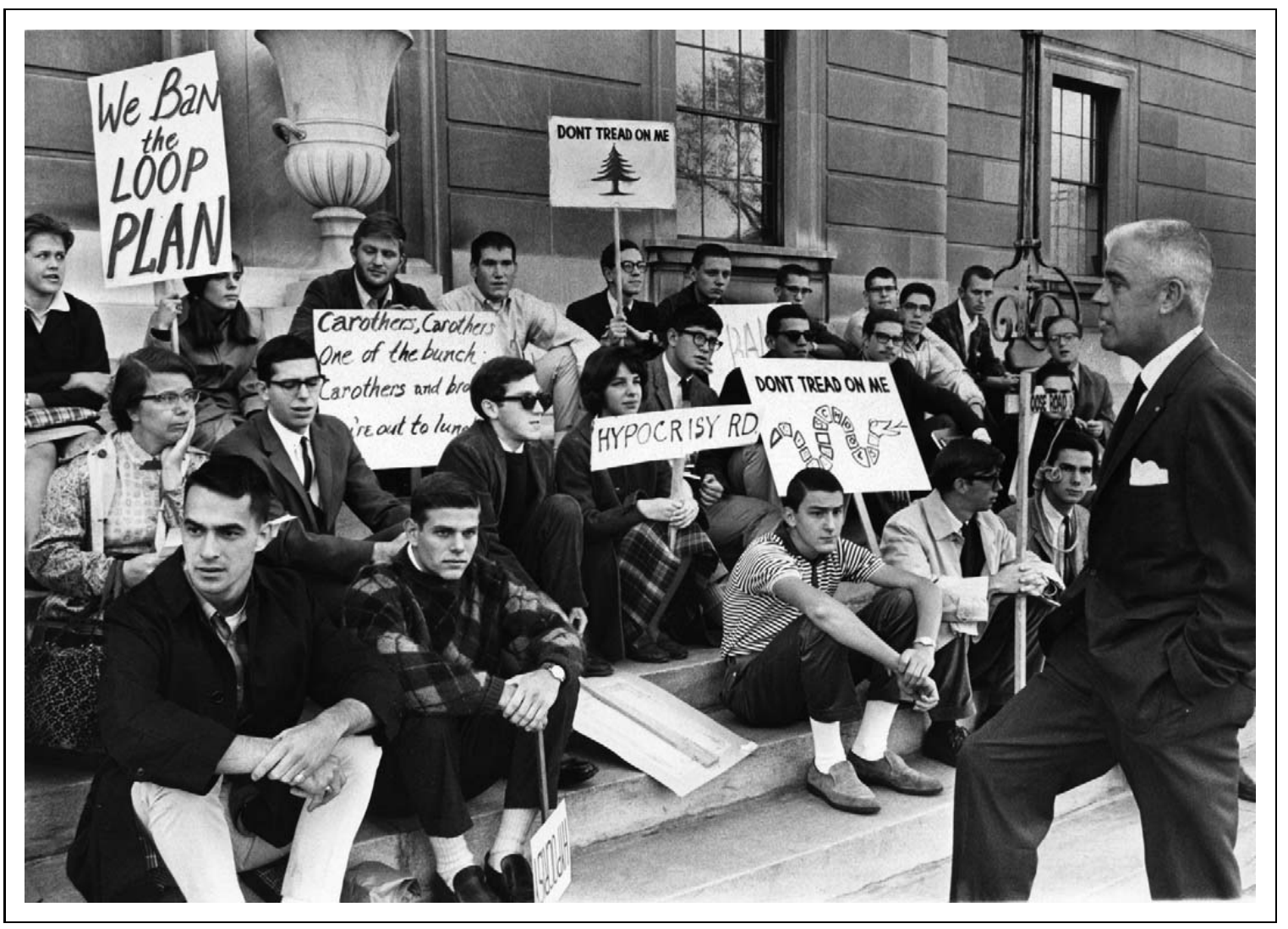

Figure 7. UCDF president Neil J. Carothers addresses protesting Western Reserve students, 1963. WRU stu dents led the fight against the proposed loop road that Circle institutions envisioned. The protests, like those against Columbia University's proposed gymnasium in Morningside Park five years later, suggest the challenges of UCDF's development plans. Source: Cleveland Press Collection, Cleveland State University.

second building got underway soon thereafter, but the UCRC never found enough tenants to fulfill its original plan to employ more than seven thousand five hundred "brainworkers." 44

Beyond the bounds of University Circle, where the big three institutions committed money to take projects beyond blueprints, the renewal project sputtered. Overshadowed from the start by Erieview, which had filled municipal officials' heads with sugarplum visions of blocks of development surrounding Galbreath's forty-story, green-glass sheathed tower, University-Euclid became mired in the city's larger failure to administer its ambitious and expansive renewal campaign for more than six thousand acres (Figure 9). From its inception, University-Euclid lacked adequate planning staff, and the resulting gap between promises and action discouraged property owners from investing in the Hough area. As the 1960s passed, the hope of rehabilitation was dashed as hundreds of more homes deteriorated beyond repair, many of them victims of the attitude that it was a waste to fix them up when the city was eyeing them for purchase. ${ }^{45}$ Although University Circle's officers and trustees included downtown bankers, business leaders, and utilities chiefs who championed both hubs, University-Euclid labored under less than ideal political circumstances. Cleveland's civic leaders commanded much less national attention than was the case in Chicago, where powerful university trustees enjoyed influence with both the Daley and the Eisenhower administrations. University-Euclid's large area beyond the Circle itself attracted no James Galbreath to take advantage of Circle institutions' development and encompassed many small pockets of rather mundane improvements that never shared the city administration's commitment to downtown. ${ }^{46}$ 


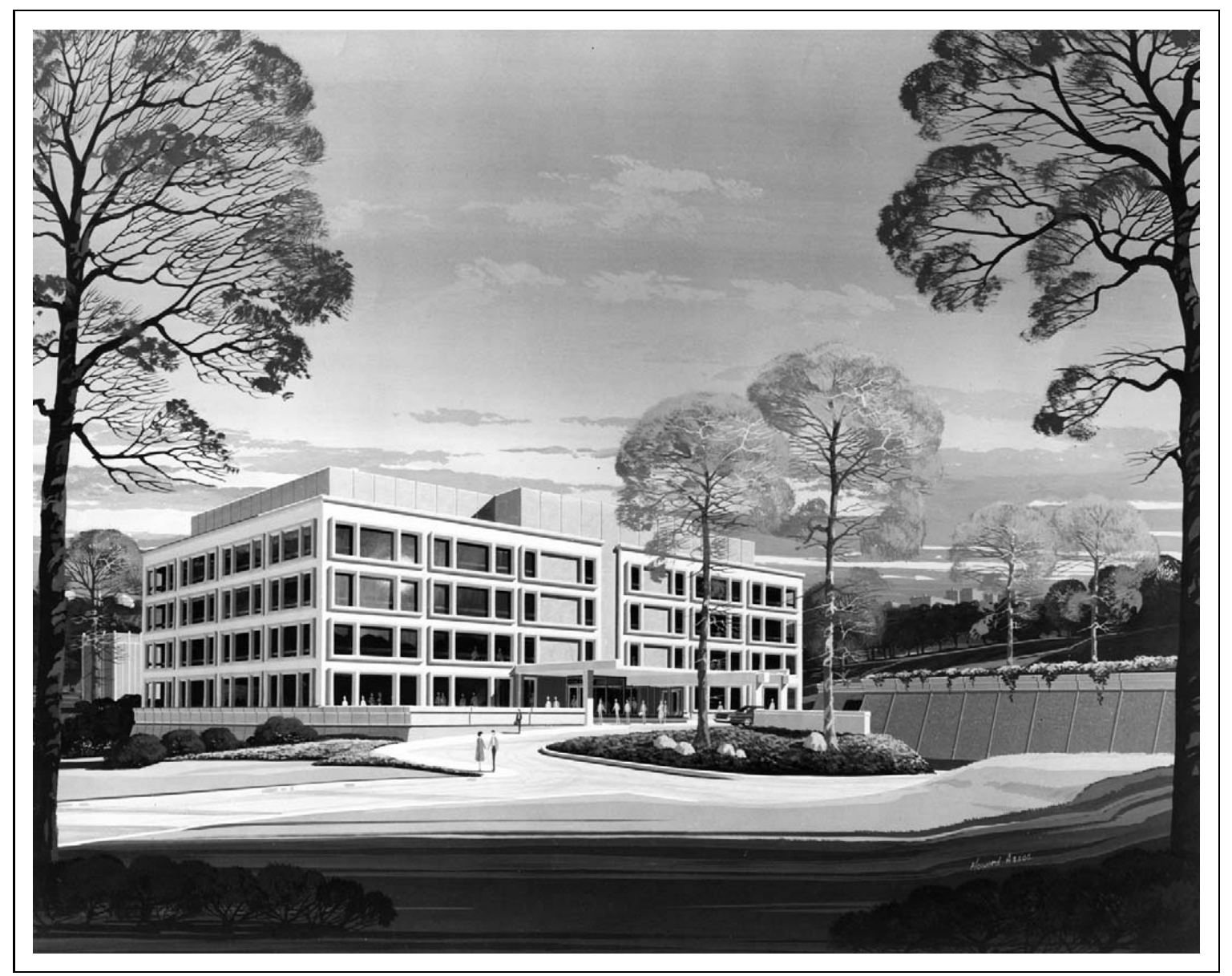

Figure 8. Artist's rendering of University Circle Research Center, 1966. Case and Western Reserve leaders hoped that a research park on the southern edge of University Circle would bolster Cleveland's reputation as a manufacturing and headquarters city that might compete head to head with East and West coast and Sunbelt cities. Source: Cleveland Press Collection, Cleveland State University.

\section{Making the Circle "As Safe As Your Own Living Room"}

Understanding that urban renewal, even if successful, would take years to reverse trends in Hough, Circle leaders worried that the public might view University Circle as losing ground in its fight against decay. Normally upbeat, Neil Carothers warned in 1960 that "no apple stays good for long when there are bad apples around it." ${ }^{47}$ Institutional leaders were especially concerned about crime along the Circle's border with Hough, whose African American population soared from 14 to 75 percent in the 1950s. Between 1954 and 1958, as eastern Hough was undergoing rapid racial transition, Mt. Sinai Hospital acquired 131 units of nearby rental housing in anticipation of federal urban renewal. A series of incidents in the summer of 1958 convinced Mt. Sinai director Sidney Lewine that the area was in serious trouble. He cited two recent attacks on women near the hospital, a letter from an out-of-town student nurse expressing hesitation about enrolling in Mt. Sinai's School of Nursing as a result of reports about the neighborhood, and the unwillingness of one patient's visitor to park in a nearby hospital lot in the evening. Echoing the logic of the superblock approach to planning, Lewine recommended the closure of through streets near the hospital to enable hospital security patrolmen to guard the campus more tightly but suggested that the only real solution was "a substantial urban renewal program 


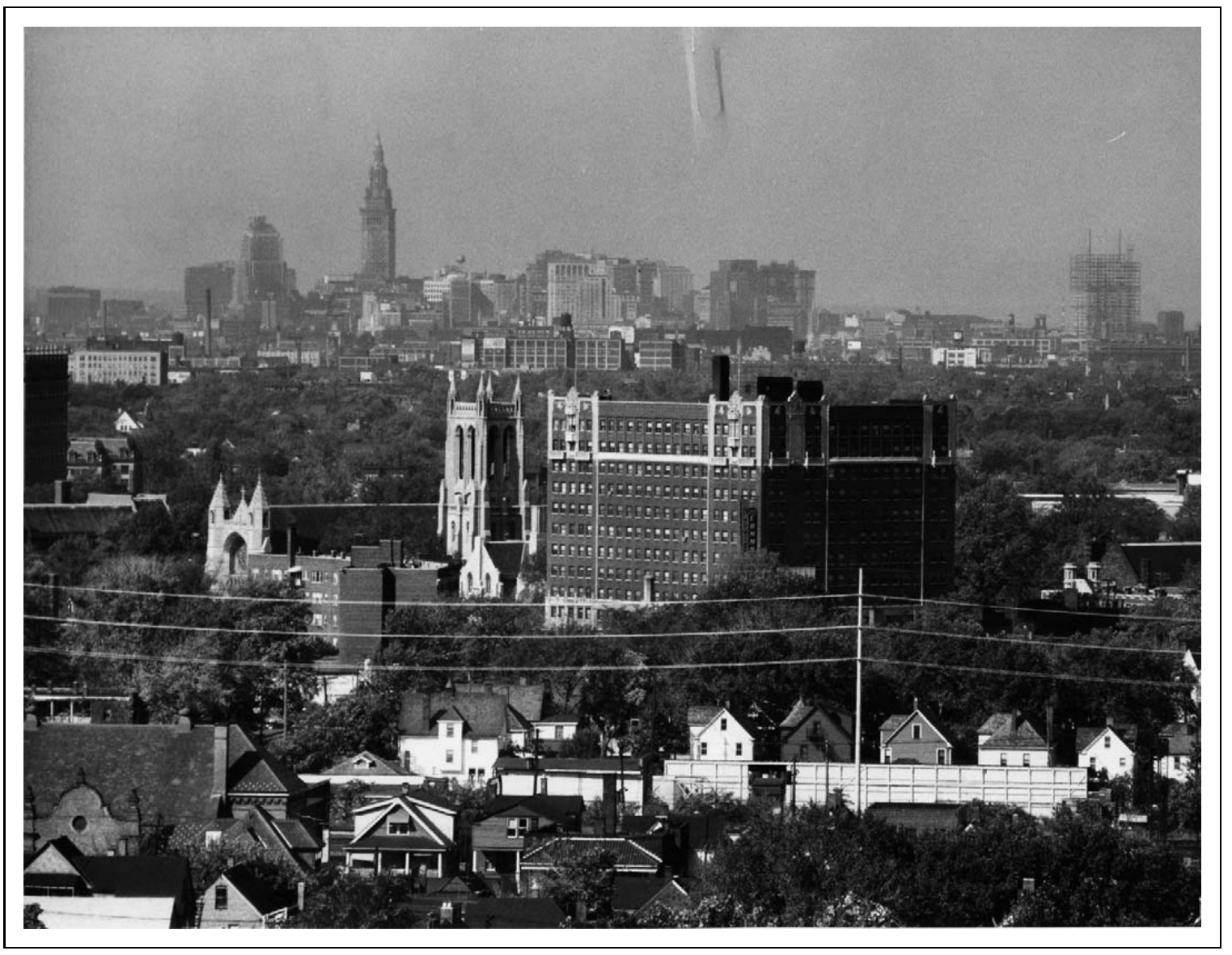

Figure 9. University Circle with downtown Cleveland in background, 1964. The Erieview urban renewal proj ect's forty story tower, under construction, is visible on the skyline at right. Source: Cleveland Press Collection, Cleveland State University.

... to attract and hold desirable residents in this area." When the Salvation Army opted to sell its Evangeline Home, a residence hall for young women at 1588 Ansel Road, Lewine worried that the sale might eliminate the homes of a number of Mt. Sinai's employees and also "contribute to the decline of our immediate neighborhood." He urged UCDF to "guide the purchase" of Evangeline Home, implicitly to ensure that it would not become subject to blight. ${ }^{48}$

Circle institutions' assumptions about the dangers surrounding them constrained their ability to forge meaningful collaborations with neighborhood stakeholders, despite the fact that the 1957 master plan had recommended making such connections. Concerns that crime might undermine the effort to mold a renowned cultural district prompted UCDF to examine unifying the various security forces that patrolled the buildings and grounds of Circle institutions into a full-fledged Circle police department. The Cleveland Press applauded this initiative "to patrol and protect the city's cultural vault." The Cleveland Police Department, however, frowned on the move, complaining that institutional leaders were "misinterpreting crime statistics" and did not need "a vigilante patrol." Undeterred, in 1959 UCDF organized the University Circle Police Department (UCPD) and pressured the municipal government to build its new Fifth Precinct station across Euclid Avenue from the Fine Arts Garden, promising to "make University Circle as safe as your own living room." 49 Nevertheless, into the 1960s, Circle institutions harbored deep concerns about the negative impression that visitors might have about their location's security. In 1962, William Scheele, director of the Cleveland Museum of Natural History, worried that, along with 
its great distance from many among Cleveland's increasingly suburban population, the museum faced "vandalism, theft, and a generally unhealthy climate." He claimed that the museum's proximity to a largely African American neighborhood, coupled with reports of crime in the Circle, gave the public pause about visiting. ${ }^{50}$

UCDF leaders, likewise, understood that the perennial influx of greenhorn students and hospital interns and residents offered tempting targets for criminals. In 1961, UCPD officer John Howard pointed to the presence of "hoodlums" eager to prey upon unsuspecting patrons of a number of bars and restaurants on the edges of the college and hospital campuses. He also sounded the alarm on the racial dimensions of crime, pinpointing the Glenville neighborhood, where "[w] hite students wandering north of Wade Park Avenue .... at night have on several occasions been set upon by teen-age colored boys, beaten and robbed," and Little Italy, where "colored men walking singly or in pairs have been attacked by gangs of white youths .... The racial antagonism here is fairly evident." As racial residential transition rolled eastward through Glenville in the 1950s, Little Italy became a hotbed of unrest, a trend that would intensify as a result of residents' hostility toward the bussing of black students from Hough to attend Murray Hill Elementary School in 1964. Howard urged that Circle institutions figure out a politic manner in which to broach the subject to their new arrivals, adding, "I would not like to think what would result if, for example, the son of some prominent official of one of the 'emerging African neutral nations' attending Case or Western Reserve, should on a hot summer evening, wander down Mayfield to Murray Hill Road." The institutions acted accordingly, admonishing their employees and students and supervising their movements as closely as possible. ${ }^{51}$

Of particular concern because of its location at the western gateway to the Circle was the EuclidEast 105th area, which was by the late 1950s starting to resemble New York's tawdry Times Square. In 1958, the president of the Motion Picture Council of Greater Cleveland, a resident of suburban Euclid, corresponded with UCDF and several Circle institutions about the deterioration of the once grand Keith's 105th Street Theater "into an exploitation house" featuring salacious films. She deplored its ill effects on shoppers and students in the area and "the danger inherent in the type of people attracted to the neighborhood by such films," urging Circle leaders to take action ${ }^{52}$ Recurring incidents and complaints in the Euclid-East 105th area suggested that others shared her sense of danger $^{53}$ (Figure 10).

With the University-Euclid renewal plan ensnarled in delays, institutional leaders looked to the prospect of freeways creating barriers between sagging neighborhoods and their campuses. As state highway officials wrangled over building several new freeways on Cleveland's east side in the mid1960s, UCDF applauded plans for the Bedford Freeway, which if built would do what UniversityEuclid had yet to accomplish-eliminate the troublesome Euclid-East 105th district, replacing it with a multilane artery between the Cleveland Clinic and University Circle. Yet, the proposed freeway would also have endangered access to parking for Temple Tifereth Israel. Responding to Rabbi Daniel J. Silver's opposition, Neil Carothers argued that the freeway would "eliminate the cancerous 105th and Euclid situation," adding that he believed urban renewal a remote prospect. Without some sort of renewal, he warned, the future of the Temple, Mt. Sinai, and even Case in the Circle might prove "untenable." Although foundation officials took no public position on the freeway plan, privately they remained hopeful for any buffer against what they saw as a dangerous slum to their immediate west. ${ }^{54}$

\section{0s Riots and the Fortress Mentality}

With UCDF already unsettled by the degradation it perceived on the Circle's perimeter, the eruption in 1966 and 1968 of two major race riots within a mile of the district only heightened the alarm (Refer to Figure 2.). Although the riots occurred outside its borders, they cast in sharp relief 


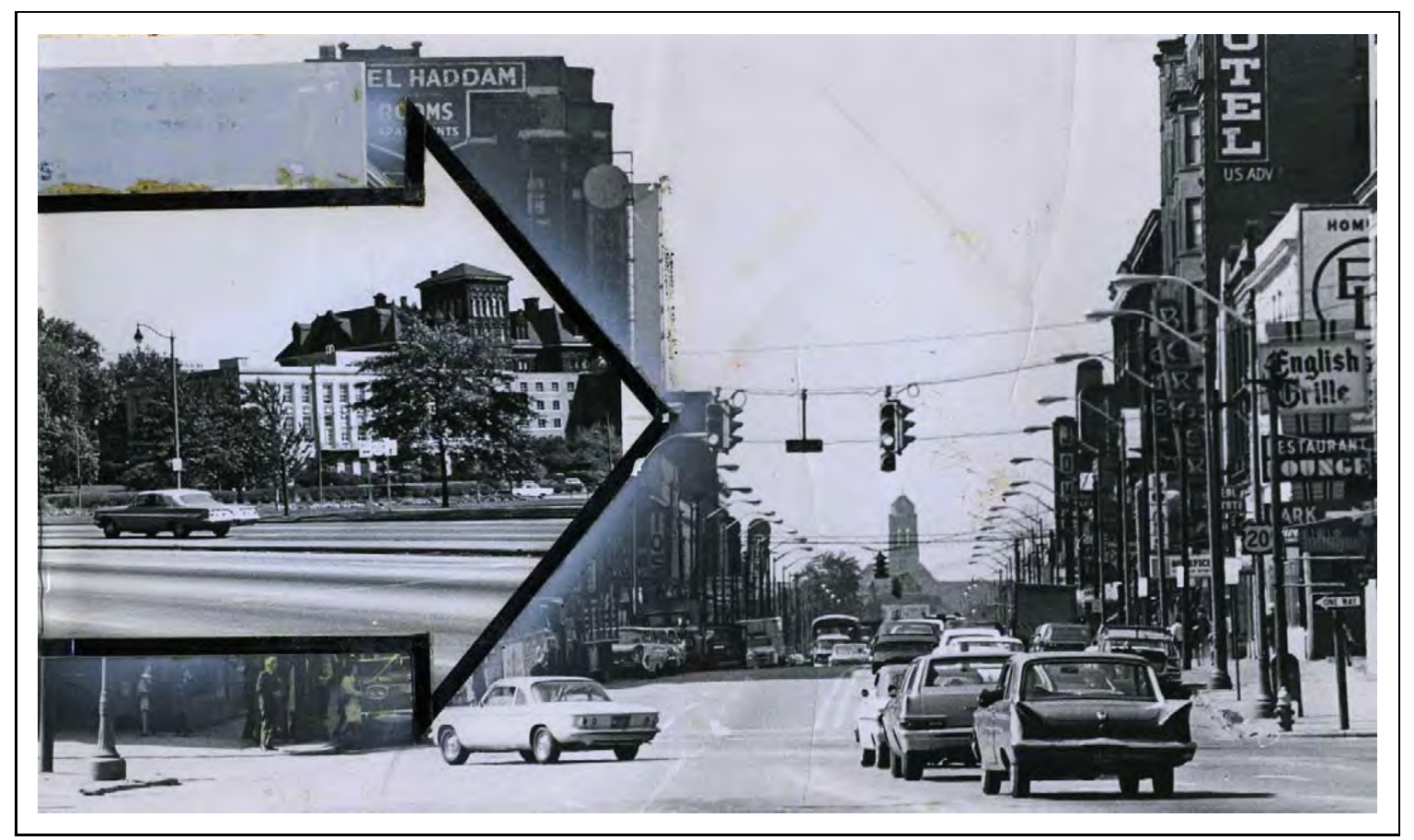

Figure I 0. A Ceveland Press collage showing the proximity of Cleveland's "second downtown" to University Circle, 1967. The Euclid East 105th area, immediately west of University Circle, underwent the same deteriora tion common in many American downtowns after World War II, as affluent citizens flocked to suburban residences. Lacking the authority to redevelop the district due to the stagnation of the University Euclid plan, Circle leaders hoped a proposed freeway might eliminate the "cancerous" strip. Source: Ceveland Press Collection, Cleveland State University.

University Circle's dilemma between building the city's second core to appeal to suburban Clevelanders and building it as a place within the reach of those who inhabited more disadvantaged surrounding neighborhoods. For several years, Circle leaders had understood that anger could reach a boiling point among those living in overcrowded, substandard housing on Cleveland's east side. It would thus be a mistake to characterize them as oblivious to the potential for disturbances in the midst of the city's cultural heart. Their reasons for concern lay in the intersection of deteriorating neighborhoods and growing African American populations, the Circle's dearth of meaningful engagement with the black community, and the emergence of the United Freedom Movement (UFM), a Cleveland-based coalition of several dozen civic, fraternal, social, and civil rights organizations that formed in 1963 to tackle a range of issues facing African Americans through negotiation and, if necessary, direct action. ${ }^{55}$

The 1957 master plan had suggested establishing a concert of interests between the institutions and their neighbors but had focused on bricks and mortar to create a bulwark against spreading decay. By the early 1960s, UCDF was beginning to project at least the image of engagement with surrounding communities. A May 1962 foundation memo cautioned that "[a]ny activities that tend to imply that University Circle is an island, a 'city within a city,' a walled fortress standing against a sea of decay, will in the long run be harmful." It recommended that the Circle's planning area boundaries be deemphasized and that no "Welcome to University Circle" signs be placed to demarcate boundaries, which "give people outside them something specific to resent, fear, and blame." 56

Two and a half years before the 1966 Hough riots, UCDF's newly hired Community Services Coordinator Michael Copperman prepared a report on the Circle's relationship with surrounding neighborhoods that reflected his belief that Hough was a powder keg. He argued that, for many 
nearby residents, "the Circle represents the summit of power, wealth, and everything else that is beyond their reach," adding that the Circle "becomes a white extension of the suburbs." He traced this suspicion to UCDF's roots in institutions' desire "to turn the tide" against "the encroaching blight." Doubtless concerned that militants in the UFM might influence its direction, Copperman pointed out that the UFM, like the black community itself, made no distinction between individual institutions, UCDF, and the Circle area. Thus, he posited, Circle institutions "must never become the target of a racial demonstration on the part of the U.F.M." He called on member institutions to attempt to integrate their boards of directors, hire African Americans in official capacities, and examine the demeanor of "the guards in the museums, the parking lot attendants, and the like" toward blacks. ${ }^{57}$ Copperman's appeal suggests that Circle leaders understood the potential for racial violence but failed to grasp the depth of the problems that ultimately led to two riots.

Even before the riots, Circle leaders tried, albeit in a fumbling way, to connect to adjacent communities, especially Hough. They offered a scholarship program, summer jobs and enrichment programs for youths in Circle museums, and collaborations with neighborhood organizations. White Circle leaders repeatedly professed their faith in Dargan Burns, an African American public relations consultant and civil rights leader who had also been the first black member of the Circle's staid Church of the Covenant on Euclid Avenue. UCDF hired Burns in 1965 to serve as a liaison that might more effectively present "the Circle program in the Negro community." In March 1966, nearly four months before the Hough riots erupted, Oliver Brooks wrote Western Reserve University president Dr. John S. Millis to warn him of the folly of assuming that surrounding communities understood and accepted the Circle's development program. Brooks intoned that "there are truly explosive racial potentials, particularly in the Hough area, at the present time, and I feel we have no choice but to reach out," suggesting again that the riots were not entirely unforeseen. He urged WRU to designate a representative to join in a dialogue already underway between a token few Circle leaders and representatives of the Hough and Glenville communities. ${ }^{58}$ Brooks' characterization of the Circle as forced to reach out, like the UCDF's reluctance to erect visible markers of its territory, suggests the limited nature of northern urban white liberalism in the mid-twentieth century.

While institutional leaders often spoke of the need to assuage their African American neighbors' concerns, they seemingly neglected their own role in displacing blacks from the little new housing that was built in Hough in the absence of urban renewal. Their policy of trying to fill the Circle and its surroundings with institutionally connected residents contributed heavily to such distrust. A mere two months before the outbreak of rioting just blocks away, the Social Issues Workshop of the Church of the Covenant told Keith Glennan that Case and WRU were culpable for failing to provide on-campus housing for married student families, instead "relegating part of their student problem upon the public housing authority." As a result, the only new public housing in eastern Hough-the Wade and Springbrook Apartments on Ansel Road overlooking Rockefeller Park Lagoon just north of Mt. Sinai Hospital - displaced previously black dwellings and set aside the land for "white families and white golden agers" instead of African Americans displaced by urban renewal elsewhere in the city. The two sixteen-story apartment towers became known in the area as "the White Island" 59 (Figure 11).

If Hough residents saw Wade and Springbrook Apartments as a "White Island," Circle leaders likely understood that the residents viewed their collective campus in a similar manner. Following the 1965 Watts riot in Los Angeles, University Circle was on high alert. ${ }^{60}$ Three weeks prior to the Hough riots, on the night of June 27, 1966, Cleveland experienced rioting in the vicinity of Saint Clair Avenue, less than two miles northwest of University Circle. While monitoring radio dispatches from a Cleveland police helicopter, Circle police learned that a group of about one hundred African Americans, "marching two abreast," was advancing from this area toward University Circle. Carothers recalled that sixteen officers in four UCPD patrol cars met them at the corner of Wade Park Avenue and East 108th Street on the Circle's northern border with Glenville. Noting that "[t]hey 


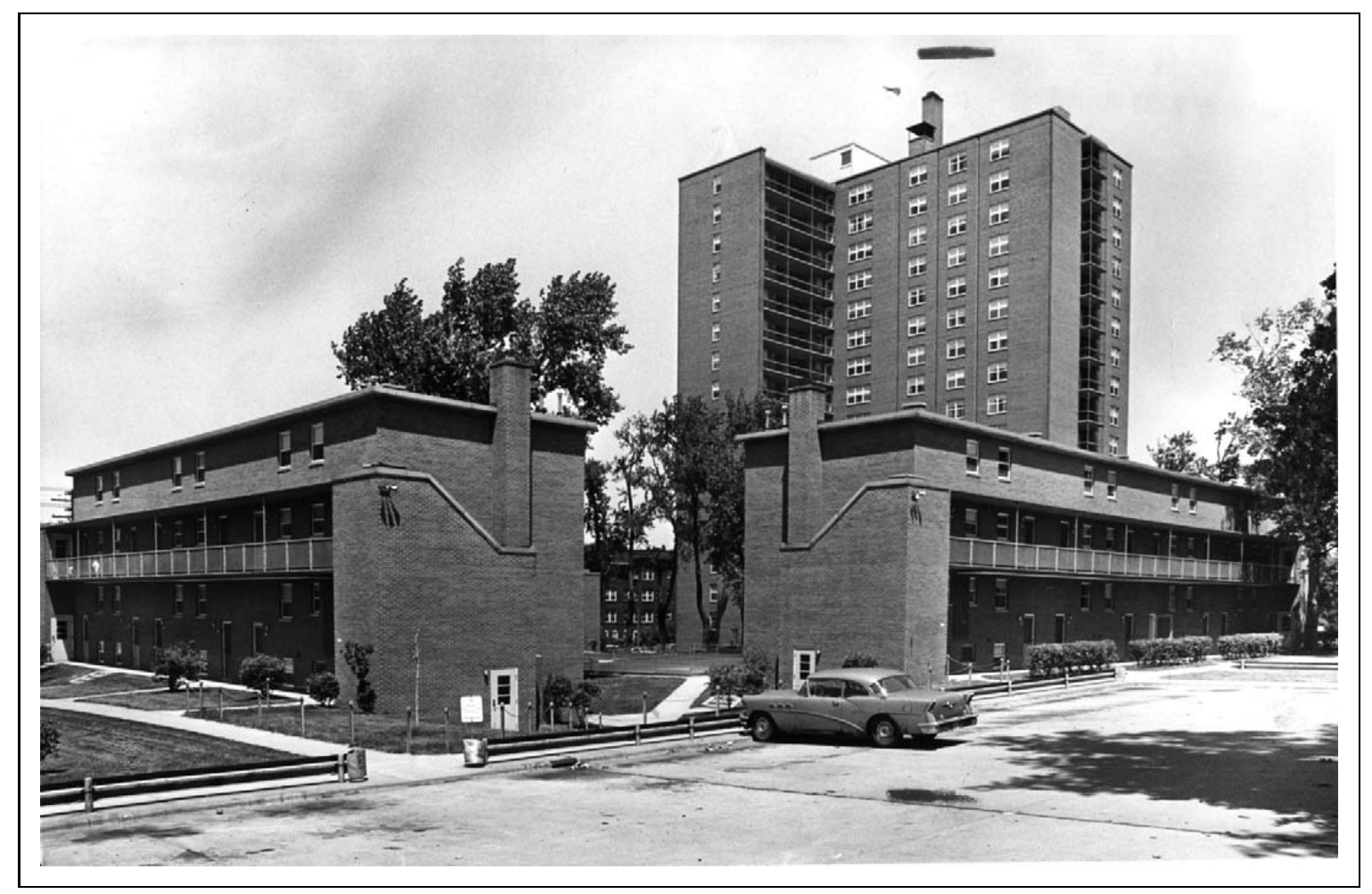

Figure I I. Wade Apartments in eastern Hough, 1966. Derided by some as a "White Island," the new apart ments symbolized Circle leaders' longstanding policy of "seeding" white residents affiliated with their institu tions to create buffers where the cultural district abutted neighborhoods that underwent rapid racial transition in the 1950s. Source: Cleveland Press Collection, Cleveland State University.

were carrying rocks and bottles, and probably fire bombs," he recounted how the patrolmen, backed by a Cleveland police helicopter hovering overhead, escorted them southward on East 108th, past the Museum of Natural History, and out of the Circle on Hough Avenue. While the marchers' intentions are unclear, Carothers believed that they were either seeking a confrontation or rehearsing for some later assault on the Circle. ${ }^{61}$

When the Hough riots broke out on July 18, University Circle leaders mobilized again out of fear that the Circle would be a target for violence. Two days into the weeklong unrest, Carothers told fellow Circle leaders that the UCPD was ready to move in "with riot equipment when the trouble moves within a few blocks of the area." He added that Circle police were posting roof spotters to alert their comrades on the ground should rioters breach the Circle. ${ }^{62}$ UCDF also arranged to house 730 National Guardsmen in University Circle to remove them from more distant armories in Shaker Heights and Warrensville Heights, suggesting the nervousness that infused the Circle. While the rioting never penetrated the Circle itself, UCPD officers gave chase to "a stolen car occupied by four Negro juveniles," and an arson fire and shooting of an African American family occurred behind WRU's Graduate House (formerly the Tudor Arms Hotel) ${ }^{63}$ (Figure 12).

Hardly surprising, the riots reflected pent-up anger among African Americans who faced great difficulties in finding adequate housing. Urban renewal projects had by the following year displaced nearly 4,500 families, about 2,400 of whom found no new dwellings opened up through these projects. University-Euclid was among the biggest failures. With the eastern city limits only recently having ceased to be a fortress wall maintained by discriminatory lenders and real estate brokers, not to mention developers who offered little affordable suburban housing and a Cuyahoga River that 


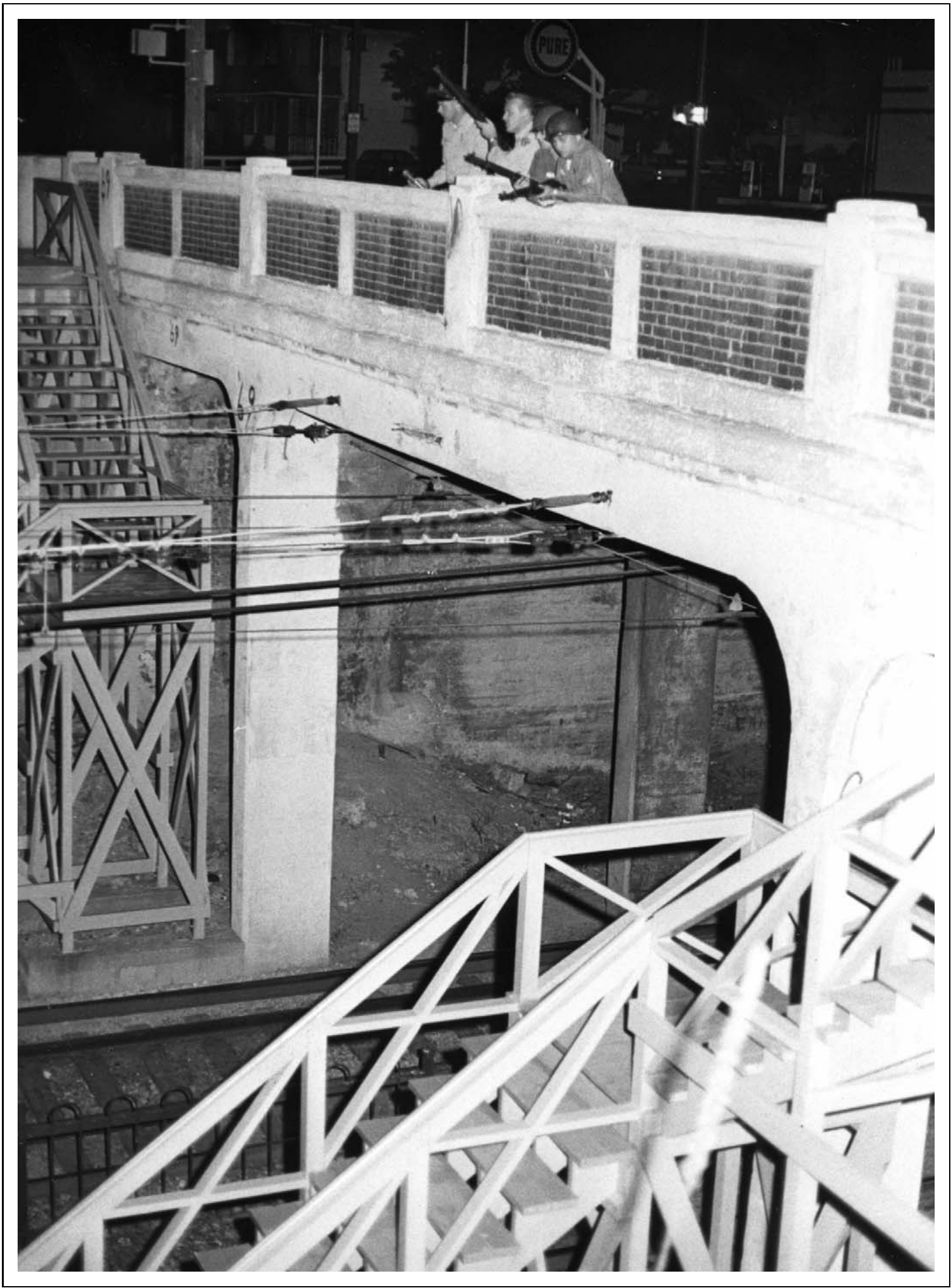

Figure I 2. National Guardsmen stand watch on the East I 6th Street overpass above the Shaker Rapid transit line during the Hough riots, 1966. The National Guard patrolled not only University Circle but also key points of entry into the nearby Heights suburbs, suggesting that suburbanites invested both hope and fear in the Circle. Source: Cleveland Press Collection, Cleveland State University. 
ethnic whites had long maintained as a barrier to black residence on the West Side, there was little to do but remain trapped in worsening slum conditions. ${ }^{64}$

Following the Hough riots, University Circle leaders struggled to identify ways to quell the violence that came disturbingly close to the city's cultural heart. On the evening of August 30, Carothers met with the black nationalist J. F. K. House organization's director Lewis G. Robinson in the steamy back room of a dress shop on Superior Avenue near East 93rd Street to discuss the riots and African Americans' concerns. Robinson blamed the city's white power structure, citing the Chamber of Commerce, Cleveland Development Foundation, and UCDF - all great cheerleaders of urban renewal in Cleveland - as some of its most visible symbols. According to Carothers, Robinson "made it crystal clear that he and his followers fully intend to continue their rifle and riot approach." 65 Indeed, Circle leaders began to fear the growing specter of black nationalism, symbolized by the visibility of the Cleveland-based Afro Set organization, the discovery of black nationalist ties to the subsequent Glenville Shootout, and a series of smaller incidents on the periphery of the Circle in the late 1960s. In late 1967, for instance, four African American youths "later identified as members of a militant black nationalist movement" assaulted a UCPD patrolman on East 105th Street outside the Park Lane Villa, a residential hotel overlooking Rockefeller Park. ${ }^{66}$

The riots only aggravated public fear, belying regular UCDF assurances that the Circle remained safer than the city as a whole. The rape and murder of a Shaker Heights woman in the Fine Arts Garden across from Severance Hall in autumn 1966 underscored University Circle's image as a place on the edge. ${ }^{67}$ Although the UCPD dispatched a helicopter to hover nightly above the Circle and prodded the city to install improved street lights that its utilities director promised would bring "near-daylight brightness," fear continued to grip the area. Two years later, following an attack on an Allentown, Pennsylvania, museumgoer in the Fine Arts Garden, UCDF revealed plans for even brighter forty-foot-tall streetlights like those used to illuminate shopping mall parking lots. ${ }^{68}$ Despite such efforts to squash crime, the Circle remained insecure.

The growing fear of white suburbanites prompted regular discussions about how institutions could remain viable as an image of rampant crime constricted their ability to convince workers and patrons, who increasingly resided in sheltered suburbs, of the relative safety of University Circle. In spring 1967, Mt. Sinai director Sidney Lewine noted three recent rapes, adding that "refusal to work in the neighborhood" constituted the chief obstacle to the hospital's recruitment and retention efforts, a problem compounded by the fact that some 80 percent of Mt. Sinai's workers were women. With a twenty-three-bed ward already closed because of the staff shortage, Mt. Sinai increased its waiting period for nonurgent surgical procedures to eight weeks. Worse, Lewine feared, the hospital's staff might react "to speeches transmitted over television and in the newspapers predicting the repetition of the Hough riots early this summer. We hear rumors that penetration of the University Circle area is being contemplated, and ... that attacks just up to or into our hospital have been discussed." ${ }^{69}$ Lewine called upon UCDF to quell public fears, noting that Mt. Sinai was receiving "more questions as to the validity of our decision made a dozen years ago to remain and expand our institution in this area." He implored UCDF, in its informational presentations to various groups, to emphasize "the factors which make this the ideal location for a teaching hospital," adding that "the Mount Sinai area should show up as part of the University Circle area"- not Hough. ${ }^{70}$

While race usually remained a subtext in Circle leaders' discourse, the spectacular growth of the African American population, combined with the Hough and Glenville riots, provoked considerable consternation. By 1969, the director of the Cleveland Museum of Natural History, located just east of Mt. Sinai, wrote the museum's president Marie Odenkirk Clark to express concern about its future in the Circle. He told her that in the twelve years since the museum left its former home in a Euclid Avenue mansion to make way for Interstate 90, a "decided increase in harassment to our visitors, premises, and staff" was exacting a toll on visitation and, as was true at Mt. Sinai, "efforts to secure and hold new staff." In a thinly veiled euphemism for black youths, he referred to the "increased 
presence of largely inner-city, federally funded groups" whose "loud, uncontrolled, abusive, and generally disrespectful" demeanor offended "paying visitors" to the extent that he predicted a decline in visitation to University Circle. ${ }^{71}$

By the end of the 1960s, UCDF stood at a crossroads. A decade earlier, the 1957 master plan had produced ebullient anticipation of sweeping change in and around Cleveland's cultural heart. Having completed "the most exciting and visible parts of the development," it was harder to motivate civic leaders to bankroll Circle plans. In a letter typical of those sent to potential donors in 1969, a UCDF official reminded Sohio chief Charles Spahr that the Circle was "one of the great centers of creative thought and work" that still made Cleveland "a place that attracts and holds the dynamic leaders and their families [and] that in turn keeps Cleveland an outstanding place to work, live and raise a family." Noting the foundation's dilemma, a local public relations consultant explained, "The Circle has been saved, so to speak." Yet many people "from all over northeastern Ohio" were also staying away from the Circle because of concerns for their safety. In a sense, the Circle's fortunes on the eve of 1970 mirrored those of Cleveland itself, a city plagued by the physical and psychological scars of deindustrialization, depopulation, failed urban renewal, two riots, and the widely publicized Cuyahoga River fire. ${ }^{72}$

\section{Conclusion}

The transformation of University Circle into an institution-dominated district, much of it cast by the 1957 plan, was largely manifest by the 1970s. To be sure, a few of the plan's most touted features never materialized. A combination of activism and environmental hurdles checked plans to create a large pedestrian zone encircled by the aforementioned loop road. While protests pared down the planned loop road to two short segments (called Circle Drive) on the area's eastern fringe, the Euclid Avenue plaza succumbed to concerns that a subterranean street would invite flooding. Then, in 1969, student protests persuaded UCDF to relent in its effort to de-map Hessler Road and Hessler Court, a pair of brick and wood-block streets lined by early twentieth-century houses and apartment buildings one block north of Euclid Avenue. As a coordinator of parking, landscaping, and institutional expansion, however, the plan certainly advanced institutional goals. ${ }^{73}$

In 1970, University Circle Incorporated (UCI) was born in response to soul-searching by Circle leaders after more than a decade of charges that UCDF harbored a fortress mentality toward surrounding neighborhoods. While UCDF had implemented much of its plan to recast the Circle, it suffered a lack of goodwill from the city around it. Much like the situation historian Matthew Countryman describes in the aftermath of the North Philadelphia riot in 1964, its leaders' faith in token efforts to reach out to surrounding neighborhoods had lost its luster in the wake of two race riots on its doorstep. Accordingly, under former Case Western Reserve University officer Joseph D. Pigott's leadership, UCI exploded its insularity, expanding its board of trustees from 9 to nearly 100 members to achieve a broader sense of ownership in its policies. The organizational transformation, it turns out, only partially carried over into substantive policy changes. ${ }^{74}$

After UCDF reorganized as UCI, it assumed a more collaborative posture toward its neighbors. Some of its efforts reflected a change in thinking from previous years. For instance, it cultivated an image of moving away from privileging construction projects to stabilizing surrounding communities by partnering with two civic groups, Citizens for Better Housing and Homes for Hough (an arm of the Hough Area Development Corporation). The partnership produced Community Circle Estates, comprising a ten-story apartment building and two clusters of townhouses totaling 160 housing units just west of Mt. Sinai and Rockefeller Park. ${ }^{75}$ This action represented a change from the earlier tendency to try to place Circle associates and students in what little new housing opened in Hough. 
However, some things remained much the same. Continuing a trend of bulldozing neighborhoods to serve institutions' needs, UCI now echoed earlier efforts to level homes in the vicinity of Murray Hill Road, East 115th-118th streets, and Hessler Road. Just as residents had opposed such efforts in the 1960s, the 1970s brought renewed efforts to protect what little housing remained in the Circle. UCI drew fire from student protesters when it tried in 1976 to revive its plan to build a loop road that threatened to eliminate a cherished pocket park between Cornell and Abington roads and lop off the back yards of houses on the section of East 115th Street south of Mayfield Road, one of the Circle's last surviving residential pockets. One local whistleblower charged that UCI's goal was to "sanitize" the Circle "by driving out present occupants" and "seal off the Circle from the largely black surrounding area by roads." 76

The following year, the newly formed University Circle Tenants Union fought to save East 115 th Street, which stood in the path of a potential University Hospitals expansion. The Tenants Union picketed the UCI headquarters, and some sixty-five union members caravanned to Pigott's Cleveland Heights home to deliver a letter protesting UCI's failure to listen to their demands. ${ }^{77}$ A Plain Dealer article later that year noted that in the previous two decades, University Circle lost more than 230 houses and apartment buildings, displacing some three thousand residents. It called attention to the danger that the Circle was "becoming yet another living and breathing neighborhood suffocated under the guise of urban renewal" and predicted that UCI's vision was to replace a green, people-friendly preserve with "a sterile wilderness of cold concrete and asphalt in University Circle, a harsh forbidden zone whose only residents will dwell in highrise 'mini-city' apartments far removed from the street world below." ${ }^{, 7}$ UCI relented in its battle with Circle tenants, striking a deal to offer fairer leases and rehabilitate and maintain houses it had neglected for years in anticipation of demolition. The action, like its gestures to Hough, reflected a combination of citizen activism and Circle leaders' growing realization that they needed at least some token neighborhoods to head off ongoing charges that the Circle was becoming an acropolis fortified against its neighbors.

Ever concerned about University Circle's image, UCI also continued to take a vigilant stance to allay fears associated with public perceptions of the Circle as a dangerous place. Circle leaders began exploring collaboration with the Cleveland Clinic Foundation to encourage the Clinic's eastward expansion, which might finally erase the blighted Euclid-East 105th area that had once served as Cleveland's second downtown. Clearly a heavily scripted district like University Circle was seen as preferable to the traditional urban district with its potential for unwanted encounters. In 1972, UCI installed the nation's first 24-hour outdoor surveillance system, on the cusp of a national drift toward the privatization of public space. During a demonstration for a Plain Dealer reporter, the cameras captured "three hippies swimming among the ducks" in the Fine Arts Garden lagoon and, after panning right, "some boys rolling down a grassy slope." 79 Little was left to chance in the campaign to ensure a predictable experience in Cleveland's master-planned eds, meds, and cultural district.

In subsequent years, particularly in the 2000 s, UCI would rethink earlier planning, moving away from physical transformation to mimic suburban ideals. It worked to undo the destruction of neighborhoods and businesses by re-urbanizing University Circle with its "1,000 New Homes" campaign and its "Bring Back Euclid Avenue" initiative to create new storefronts on scarred vacant land along Euclid Avenue. By that time, buoyed by a tremendous expansion of the medical industry and a halfbillion dollar transit "Healthline" eastward from downtown, the nearby Cleveland Clinic had ballooned into a mammoth, twenty-five thousand-worker health care city within a city that connected seamlessly with University Circle. Yet, its approach remained primarily focused on creating a world-class urban destination-in this way much like its longtime institutions-first approach-rather than on catalyzing broader community partnerships, as has happened with the University of Pennsylvania's West Philadelphia Initiatives in the past two decades. ${ }^{80}$ 
While it preserved institutional commitments to remain in the city and created a destination for Clevelanders and tourists, University Circle's master plan and its agents failed to recast the city's troubled east side. Although the Circle stabilized, most of the surrounding areas continued their downward slide, raising questions about the extent to which private institutional redevelopment in a secondary urban core, like federal urban renewal plans and downtown revitalization projects, truly bolsters the fortunes of the larger city. To the extent that University Circle fulfilled dreams of a second hub for Cleveland, it did so, not so much through occasionally joining hands with its immediate city neighbors as through its accommodation of suburbanites' search for security, attractive landscapes, and easy automotive access. Thus, like urban cores elsewhere, in Cleveland the search for renewal radiating from the center proved illusive.

\section{Acknowledgment}

The author wishes to thank Guian A. McKee, Todd M. Michney, and the anonymous reviewers for their insight ful comments. He is also indebted to Michney for his expertise in GIS mapping.

\section{Declaration of Conflicting Interests}

The author(s) declared no conflicts of interest with respect to the authorship and/or publication of this article.

\section{Funding}

The author(s) received no financial support for the research and/or authorship of this article.

\section{Notes}

1. A Plan for the University Circle Community: A Proposal to University Circle, Inc., Cleveland, Ohio, July 15, 1970 (White Plains, NY: Raymond, Parish and Pine, Inc., 1970), container 10, folder 251, University Circle Inc. Records (hereafter cited as UCI), Western Reserve Historical Society, Cleveland, Ohio (here after cited as WRHS).

2. On urban decline and deindustrialization, see Beyond the Ruins: The Meanings of Deindustrialization, ed. Jefferson R. Cowie and Joseph Heathcott (Ithaca: Cornell University Press, 2003); Howard Gillette Jr., Camden After the Fall: Decline and Renewal in a Post Industrial City (Philadelphia: University of Pennsylvania Press, 2005); Colin Gordon, Mapping Decline: St. Louis and the Fate of the American City (Philadelphia: University of Pennsylvania Press, 2008); Steven High, Industrial Sunset: The Making of North America's Rust Belt, 19691984 (Toronto: University of Toronto Press, 2003); Guian A. McKee, The Problem of Jobs: Liberalism, Race, and Deindustrialization in Philadelphia (Chicago: University of Chicago Press, 2008); Jon C. Teaford, The Rough Road to Renaissance: Urban Revitalization in America, 19401985 (Baltimore: Johns Hopkins University Press, 1990) and Cities of the Heartland: The Rise and Fall of the Industrial Midwest (Bloomington: Indiana University Press, 1994).

3. Some key works on urban renewal include Arnold R. Hirsch, Making the Second Ghetto: Race and Housing in Chicago 19401960 (New York: Cambridge University Press, 1983); Teaford, Rough Road to Renaissance; Joel Schwartz, The New York Approach: Robert Moses, Urban Liberals, and the Redevelopment of the Inner City (Columbus: Ohio State University Press, 1993); and June Manning Thomas, Redevelopment and Race: Planning a Finer City in Postwar Detroit (Baltimore: Johns Hop kins University Press, 1997). On urban renewal in Cleveland, see especially William D. Jenkins, "Before Downtown: Cleveland, Ohio, and Urban Renewal, 1949 1958," Journal of Urban History 27 (May 2001): 47196.

4. Few historians have explored the dimensions of urban universities and educational, medical, and cultural districts as economic development engines in the postwar period. See Margaret Pugh O'Mara, Cities of Knowledge: Cold War Science and the Next Silicon Valley (Princeton: Princeton University Press, 
2005); Michael Carriere, "Between Being and Becoming: On Architecture, Student Protest, and the Aesthetics of Liberalism in Postwar America" (PhD diss., University of Chicago, 2009); and LaDale Winling, "Building the Ivory Tower: University Development and the Politics of Urban Space" (PhD diss., University of Michigan, 2010).

5. Teaford, Rough Road to Renaissance, 120, 146.

6. See especially Thomas J. Sugrue, The Origins of the Urban Crisis: Race and Inequality in Postwar Detroit (Princeton: Princeton University Press, 1996); and Matthew J. Countryman, Up South: Civil Rights and Black Power in Philadelphia (Philadelphia: University of Pennsylvania Press, 2006).

7. John R. Stilgoe, Borderland: Origins of the American Suburb, 18201939 (New Haven: Yale University Press, 1990); James Borchert and Susan Borchert, "Downtown, Uptown, Out of Town: Diverging Patterns of Upper Class Residential Landscapes in Buffalo, Pittsburgh, and Cleveland, 1885 1935," Social Science History 26 (Summer 2002): 31146.

8. Preliminary Technical Report on a General Plan for the University Circle Area (Cambridge: Adams, Howard \& Greeley, City Planning Consultants and Anderson, Beckwith and Haible, Architects, 1957), container 50 , folder 99 , UCI.

9. On the Cold War's impact on universities, see O'Mara, Cities of Knowledge.

10. See, for example, list of Mount Sinai Hospital of Cleveland Board of Trustees, 1965 1966, container 4, folder 30, UCI. Of fifty board members, forty lived in Shaker Heights, and three each in Cleveland Heights, Pepper Pike, and Gates Mills, also on the east side. Only one board member, a resident of Wade Park Manor overlooking Wade Lagoon, lived in University Circle and, thus, in the city of Cleveland.

11. The First Five Years (Cleveland: University Circle Development Foundation, 1962), 3, Vertical File, Department of Special Collections, Cleveland State University (hereafter cited as CSU); Alfred A. Ben esch, interview by Maurice Klain, May 22, 1962, transcript, pp. 385 88, container 1, folder 28, Maurice Klain Papers (hereafter cited as MK), WRHS; Oliver Brooks, interview by Maurice Klain, June 21, 1962, transcript, pp. 364 65, container 2, folder 55, MK.

12. John S. Millis to Harold T. Clark, January 2, 1952, container 50, folder 81, UCI; John S. Millis, minutes of first meeting of University Circle Conference Committee, September 20, 1952, container 50, folder 80, UCI.

13. "Mather Gift Spurs Master Plan for Enhancing University Circle," Cleveland Plain Dealer, March 21, 1956, 1; "Circle Plans Backed by Mrs. Mather," Plain Dealer, October 16, 1957, 50; Mrs. William G. Mather to Keith Glennan, May 6, 1957, container 50, folder 81, UCI. Mather's interest in strengthening the city's cultural heart also grew out of her longtime engagement in the Circle. She had founded the Gar den Center of Greater Cleveland (now Cleveland Botanical Garden) and also worked tirelessly on plans to beautify Wade Park as a fitting campus for the Cleveland Museum of Art.

14. Brooks interview, pp. 37677.

15. T. K. Glennan, interview by Maurice Klain, September 25, 29, November 13, 1961, transcript, p. 76, con tainer 5, folder 239, MK.

16. University Circle: A Plan For Its Development (Cambridge: Adams, Howard \& Greeley, 1957), 3 5. For more on Lynch's role in shaping the modernist design principles that suffused the University Circle plan, see City Sense and City Design: Writings and Projects of Kevin Lynch, ed. Tridib Banerjee and Michael Southworth (Cambridge: MIT Press, 1990), 701 2. Other American universities, such as the University of Pennsylvania, embraced plans that created inward looking, pedestrian oriented campuses. See Judith Rodin, "The 21st Century Urban University: New Roles for Practice and Research," Journal of the Amer ican Planning Association 71 (Summer 2005): 238.

17. University Circle: A Plan For Its Development, 16 18, 5960.

18. Glennan interview, pp. 54 55; Brooks interview, p. 380.

19. "Pick Carothers to Head Circle Development," Cleveland Press, June 11, 1958, 23; Bob Reeves, interview by Matthew Ferraton, March 18, 2008, \#920005, Cleveland Regional Oral History Project, digital file available from Center for Public History and Digital Humanities, CSU. 
20. Eugene Segal, "Circle Plan Gets Its Start Today," Plain Dealer, October 16, 1957, 1; Robert Bordner, "Director to Spur Circle Plan Is Sought," Cleveland Press, October 17, 1957, 81; Grant Anderson, "Uni versity Circle Looks to the Future," Case Alumnus, December 1957, 11, container 50, folder 79, UCI.

21. John E. Bryan, "University Circle a $\$ 500$ Million Asset," Plain Dealer, November 29, 1963, 34.

22. "Weather Cuts Circle Open House Crowd," Plain Dealer, May 27, 1962, 2 AA; Allen Fonoroff to Will Burtin, March 31, 1966, container 20, folder 632, UCI.

23. See, for example, Neil J. Carothers to Donald M. Lynn, June 19, 1958, container 15, folder 444, UCI.

24. Anthony J. Celebrezze, transcript of remarks to Cleveland Engineering Society Tuesday Luncheon Club, October 24, 1961, container 3, folder 26, UCI; Neil J. Carothers to T. Keith Glennan, October 31, 1961, container 3 , folder 26 , UCI.

25. Neil J. Carothers to Mrs. T. Wingate Todd, January 26, 1960, container 15, folder 444, UCI; University Circle: A Plan for Its Development, 51; "University Circle's Future," Plain Dealer Pictorial Magazine, April 19, 1959, 2; The First Five Years, 6.

26. Raymond Q. Armington, memo to Neil J. Carothers, December 6, 1967, container 2, folder 158, UCI.

27. The First Two Years: A Progress Report on the University Circle Development Foundation (October 15, 1957 to October 15, 1959) (Cleveland: University Circle Development Foundation, 1959), 7 8, container 2, folder 180, UCI.

28. Ibid.; Neil J. Carothers to Harold T. Clark, March 10, 1960, container 20, folder 640, UCI; Paul Lilley, “Tudor Arms Sought as Dormitory," Cleveland Press, July 28, 1960, A1; Brooks interview, 361.

29. Todd M. Michney, "Race, Violence, and Urban Territoriality: Cleveland's Little Italy and the 1966 Hough Uprising," Journal of Urban History 32 (March 2006): 410.

30. "University Circle Acts Hit in Council," Plain Dealer, February 10, 1959, 1.

31. Ibid.; "Testimony Set Tonight on University Circle Land Bill," Plain Dealer, March 24, 1959, 21; “'Little Italy' Rallies Again to Fight Eminent Domain Bill," Plain Dealer, April 1, 1959, 28; Murray See ger, "University Circle Developers Get a Costly Political Lesson," Plain Dealer, March 30, 1959, 17; Paul J. DeGrandis, interview by Maurice Klain, n.d. [ca. 1959], transcript, pp. 24 [pagination starts over after p. 44], Folder 138, Container 2, MK; "Circle's 'Domain' Bill Dies," Cleveland Press, April 2, 1959; "Land Right for U. Circle Withdrawn," Plain Dealer, April 3, 1959, 16.

32. Neil J. Carothers to Dr. T. Keith Glennan, April 18, 1961, container 3, folder 26, UCI; Typescript report, "Alta Area," January 20, 1964, pp. 1 2, 5, 15 18, container 3, folder 1, UCI; Carothers to Glennan, October 12, 1964, container 10, folder 270, UCI; Carothers to Al Alissi, February 20, 1967, container 3, folder 4, UCI.

33. Neil J. Carothers to Lyle E. Schaller, January 30, 1968, container 20, folder 630, UCI; "Universities Join City in Improving Area," Business Week, September 23, 196117780.

34. Neil J. Carothers, interview by Maurice Klain, n.d. [ca. 1964], transcript, p. 78, Folder 83, Container 2, MK. The Cleveland City Planning Commission and the city's urban renewal department, likewise, deferred to UCDF for portions of the renewal plan located inside University Circle.

35. Downtown Cleveland, 1975: The Downtown General Plan (Cleveland: City Planning Commission, 1959); Eric A. Grubb to Upshur Evans, August 29, 1959, container 25, folder "Downtown Master Plan Correspondence," Cleveland Development Foundation Records (hereafter CDF), WRHS. On the shift toward privileging downtown in renewal efforts, see Minutes of Meeting of Board of Trustees, Cleveland Development Foundation, October 5, 1958, p. 3, container 1, folder "Cleveland Development Foundation Minutes of Trustee Meetings, 1954 1969," CDF. On Erieview, see Kenneth L. Kolson, Big Plans: The Allure and Folly of Urban Design (Baltimore: Johns Hopkins University Press, 2003), 75 88. On the need to connect downtown and University Circle, see Minutes of Sixth Annual Meeting, Cleveland Development Foundation, January 14, 1960, p. 8, container 1, folder "Cleveland Development Foundation Minutes Annual Meeting, 1954 1969," CDF.

36. Paul Lilley, "University Euclid Plan Gets U.S. 'Go Ahead,"' Cleveland Press, February 6, 1962, A1.

37. "University Circle A Project for Mankind; Authorities Give Views on Circle's Aims, Responsibilities to Neighbors," undated typescript in container 15, folder 444, UCI. 
38. "Review of University Circle Public Relations and Outline of Program for 1962 3," May 1962, 6, container 15 , folder 444 , UCI.

39. Ibid.

40. Helen Weinberg, “An Enquiry: Mostly Metaphysical," Circle Review, November 15, 1963, container 50, folder 96, UCI.

41. Summary of interview with Daniel J. Silver, May 11, 1962, container 15, folder 454, UCI; Summary of interview with Marvin Barloon, May 4, 1962, container 15, folder 454, UCI; Bud Weidenthal, "Developers Are Isolating University Circle Is Charge," Cleveland Press, December 2, 1967, A9.

42. On the Stanford Research Park and University City Science Center, see O'Mara, Cities of Knowledge, 97181.

43. Bill Tanner and Bud Weidenthal, "Glennan Sparks Campaign for Circle Research Park," Cleveland Press, November 21, 1961, C4; Paul Lilley, "Research Park Sure at University Circle," Cleveland Press, October 7, 1964, A1; "The U.S. Seeks Wider Base for Science," Business Week, September 3, 1966, 62, container 58, folder "University Circle Research Center I," CDF; Dr. Victor J. Danilov, "The Seduction of Science," Industrial Research (May 1965): 42 43, 48, container 58, folder "University Circle Research Center I," CDF; R. John Griefen, "A Research Park Does Not Live By Research Alone: The Success Story of Tech nology Square," Urban Land, 24 (March 1965): 5, 7, container 58, folder "University Circle Research Center I," CDF.

44. "Ground Broken for Circle Center," Plain Dealer, August 31, 1966, 6; "Construction Starts on Research Lab," Cleveland Press, January 28, 1969, A3.

45. Donald Sabath, "University Euclid Job Is Renewal at Its Worst," Plain Dealer, February 14, 1965, 1 A; Fred McGunagle, "Planner Doubts Rehabilitation Would Help University Euclid," Cleveland Press, May 17, 1967, C3.

46. List of UCDF trustees in University Circle Ten Years, University Circle Development Foundation, 1968; biographical information in Cleveland Press Collection biographical clipping file, Department of Special Collections, CSU; Neil J. Carothers, interview by Maurice Klain, n.d. [ca. 1964], transcript, pp. 6 9, Folder 83, Container 2, MK.

47. Unidentified document attached to: Joseph D. Pigott to Dr. James A. Norton, n.d., container 11, folder 309, UCI; Untitled typescript of speech by Neil J. Carothers, n.d. [ca. 1960], container 30, folder 325, UCI.

48. Sidney Lewine to Neil J. Carothers, October 20, 1961, container 4, folder 30, UCI; Sidney Lewine to Neil J. Carothers, August 25, 1958, container 4, folder 30, UCI; Sidney Lewine to Neil J. Carothers, September 16, 1958, container 4, folder 30, UCI. It is not known whether UCDF complied with Lewine's request.

49. Editorial: "Policing the City's Riches," Cleveland Press, November 15, 1958, 6; Story Is Lukewarm on University Police," Cleveland Press, November 15, 1958, 4; Typescript of speech by Neil J. Carothers to Lakewood Rotary, January 1959, p. 8, container 30, folder 325, UCI.

50. Summary of interview with William Scheele, May 9, 1962, container 15, folder 454, UCI.

51. Neil J. Carothers, memo to T. Keith Glennan, John S. Millis, and Stanley A. Ferguson, September 21, 1961, container 3, folder 26, UCI; Michney, "Race, Violence, and Territoriality," 410 13; Roldo Bar timole and William S. Davis, "Fear Stalks Circle Area Night Workers," Plain Dealer, May 28, 1965, 64. Howard's concern was prescient, for in 1970 a white mob attacked an African student, leading the Kenyan ambassador to the United States to get involved. See Michney, "Race, Violence, and Urban Territoriality," 422.

52. Joyce B. Chapman to Gentlemen, September 22, 1958; Neil J. Carothers to Elmer J. Babin, October 1, 1958; Joyce B. Chapman to Gentlemen, January 17, 1959, container 15, folder 444, UCI. While they appar ently did little in response, they remained concerned through the next decade about the further slide of the Euclid East 105th area. The last evidence of Circle leaders seeing the area as a viable commercial district came in autumn 1960, when some of the officers of UCDF gave a small donation to some property owners who planned a Christmas lighting project for the area. See Oliver Brooks to Gerald Anderson, November 28,1960 , container 20 , folder 640 , UCI. 
53. Webster G. Simon to Neil J. Carothers, October 6, 1958, container 4, folder 47, UCI; Terie L. Wilson to Neil Carothers, October 29, 1960, container 20, folder 640, UCI.

54. University Circle Development Foundation Board of Trustees meeting minutes, June 16, 1966, container 2, folder 168, UCI; Neil J. Carothers to Rabbi Daniel J. Silver, June 2, 1966, container 20, folder 632, UCI.

55. "United Freedom Movement (UFM)," Encyclopedia of Cleveland History, ed. David D. Van Tassel and John J. Grabowski, http://ech.cwru.edu (accessed August 16, 2008).

56. "Review of University Circle Public Relations and Outline of Program for 1962 3," May 1962, 12 , con tainer 15 , folder 444 , UCI.

57. Michael Copperman, "University Circle, Public Relations, and the Surrounding Neighborhood," January 30, 1964, container 5, folder 89, UCI.

58. Oliver Brooks to George D. Beasley, October 13, 1964, container 10, folder 270, UCI; Neil J. Carothers, memo to Board of Trustees, June 8, 1967, container 2, folder 158, UCI; Oliver Brooks to Dr. John S. Millis, March 25, 1966, container 4, folder 40, UCI.

59. Mrs. Mitsuko E. Marsh to Dr. T. Keith Glennan, May 12, 1966, and accompanying untitled document dated April 4, 1966, container 11, folder 318, UCI.

60. Neil J. Carothers, memo to Board of Trustees, July 22, 1966, container 2, folder 159, UCI.

61. Ibid.; Carothers to William H. Eells, September 28, 1966, container 20, folder 632, UCI.

62. Neil J. Carothers, confidential memo to Sidney B. Congdon, Stanley A. Ferguson, John S. Millis, and Robert W. Morse, July 20, 1966, container 2, folder 159, UCI.

63. Carothers memo to Trustees, July 22, 1966; Neil J. Carothers, confidential memo to President or Executive Director U.C.D.F. Member Institutions, July 22, 1966, container 3, folder 23, UCI. For scholarly accounts of the riots, see Marc E. Lackritz, "The Hough Riots of 1966" (BA thesis, Princeton University, 1968); Michney, "Race, Violence, and Urban Territoriality."

64. “Cleveland: Promise Denied," Time, June 9, 1967, http://www.time.com (accessed June 27, 2010); "Cle veland's Urban Renewal Mess," Plain Dealer, November 15, 1966, 14. For statistics on the availability of new housing units on Cleveland's East Side by census tract prior to the riots, see Family and Housing Char acteristics (Cleveland: Cleveland Real Property Inventory, 1950 1967), WRHS.

65. Neil J. Carothers, memo to Board of Trustees, September 1, 1966, container 2, folder 159, UCI.

66. Neil J. Carothers to Harry H. Stone, February 1, 1968, container 20, folder 630, UCI. The most complete account of the Glenville Shootout is Louis H. Masotti and Jerome R. Corsi, Shoot Out in Cleveland: Black Militants and the Police: A Report to the National Commission on the Causes and Prevention of Violence (Washington, DC: U.S. Government Printing Office, 1969).

67. Neil J. Carothers, memo to Board of Trustees, November 4, 1966, container 2, folder 159, UCI.

68. “Copter to Light Area of Slaying," Cleveland Press, November 10, 1966, A2; "Vapor Lights Ordered for University Circle," Cleveland Press, November 9, 1966, A1; Bud Weidenthal, "Brightest Lights Yet Set for Circle Area," Cleveland Press, December 26, 1968, A15. The re lighting project was completed in 1971. See "New Lights Brighten University Circle," Cleveland Press, November 26, 1971, D6.

69. Sidney Lewine to Neil J. Carothers, March 8, 1967, container 4, folder 30, UCI.

70. Sidney Lewine to Neil J. Carothers, March 9, 1967, container 4, folder 30, UCI.

71. William E. Scheele to Mrs. Harold T. Clark, July 30, 1969, container 4, folder 31, UCI. His statement suggests that would be visitors from Cleveland's largely white ethnic West Side would fear going to University Circle museums.

72. Raymond Q. Armington, draft letter to Chas. Spahr, March 19, 1969, container 2, folder 156, UCI; Walker \& Company, Public Relations (Cleveland, Ohio), memo to Murray M. Davidson, July 17, 1969, container 2, folder 156, UCI.

73. Dwight Boyer, "Hessler Road Hassle,” Plain Dealer Sunday Magazine, November 16, 1969, 23.

74. Countryman, Up South, 162; Donald Sabath, "Action Unit for U. Circle Seen as 'Catalytic Force,'” Plain Dealer, April 26, 1970, 8 A.

75. “U. Circle Inc. Joins Hough Estate Plan,” Plain Dealer, April 26, 1973, 11 A. 
76. Emanuel Hughley Jr., "Residents Vow to Delay New Road in the Circle," Cleveland Press Community Weekly Cleveland East Side, June 16, 1976, 1; Dale Maharidge, “University Circle: Remaining Housing Endangered," Plain Dealer, September 21, 1977, 13 A; Roldo Bartimole, "UCI Memo Shows Just How Shabby Institutions Are to Citizens Who Want Better Neighborhoods," Point of View, May 21, 1977, folder "University Circle General 1976 1977," Cleveland Press Collection, Department of Special Col lections, CSU.

77. Maharidge, "Remaining Housing Endangered;" Tim Joyce, "University Circle Tenants Picket," Cleve land Press, April 4, 1977, D8.

78. Dale Maharidge, "University Circle Begins to Fade Out," Plain Dealer, September 20, 1977, 3 B.

79. "Widening University Circle," Cleveland Press, March 28, 1972, A8; Raphael Schlesinger, "Electronic Vigil Guards U. Circle," Plain Dealer, July 28, 1972, 1 A. On the privatization of public space, see especially Mike Davis, City of Quartz: Excavating the Future in Los Angeles (London: Verso, 1990); and Variations on a Theme Park: The New American City and the End of Public Space, ed. Michael Sorkin (New York: Hill and Wang, 1992).

80. Destination: University Circle (UCI Annual Report 2009), http://www.universitycircle.org/annual2009/ uci annual website 2009.pdf (accessed June 27, 2010); Rodin, "The 21st Century Urban University," 23946

\section{Bio}

J. Mark Souther is an associate professor of history at Cleveland State University. He is the author of New Orleans on Parade: Tourism and the Transformation of the Crescent City (LSU Press, 2006), as well as several articles, and is researching a book on the political and cultural dimensions of decline in postwar Cleveland.

Post-print standardized by MSL Academic Endeavors, the imprint of the Michael Schwartz Library at Cleveland State University, 2016 